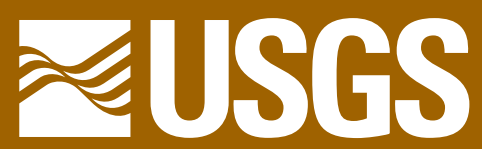

science for a changing world

Prepared in collaboration with the Albemarle-Pamlico National Estuary Partnership as part of the National Monitoring Network for U.S. Coastal Waters and their Tributaries

\title{
Estuarine Monitoring Programs in the Albemarle Sound Study Area, North Carolina
}

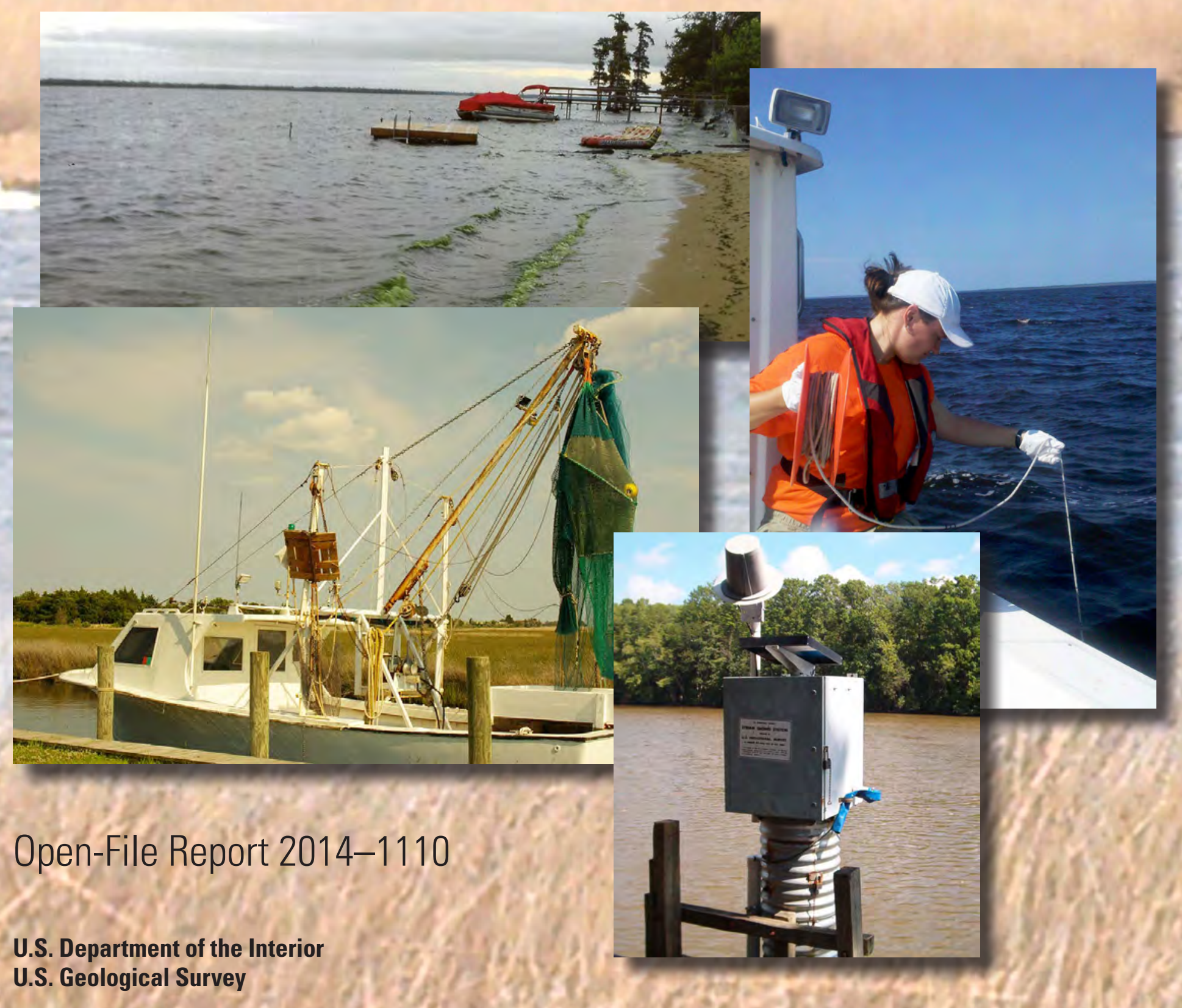




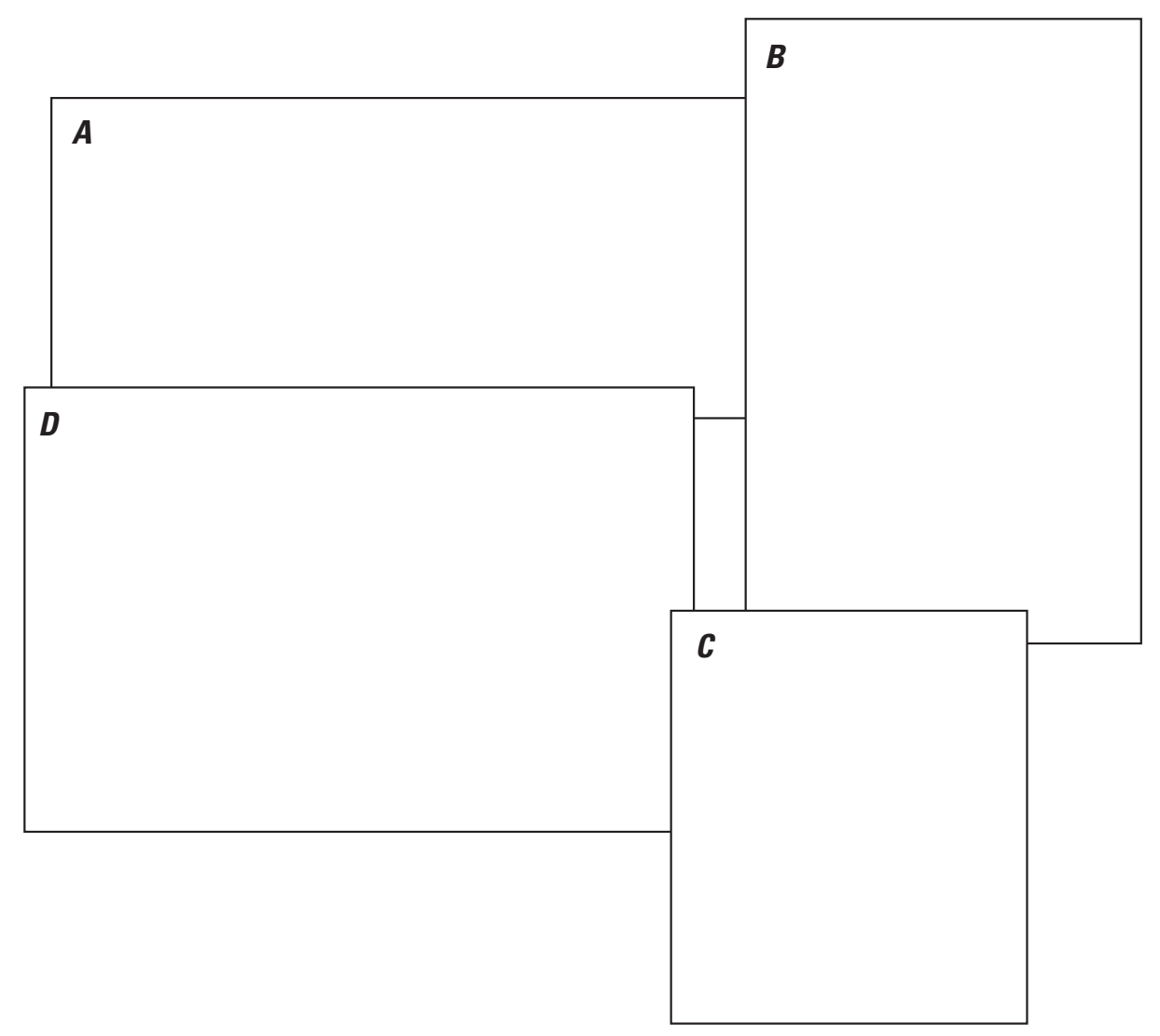

Cover. Clockwise from top left: $A$, Chowan River algae bloom, August 2013, taken by Rhonda McClenney; $B$, sampling on the Albemarle Sound, taken by Michelle Moorman, U.S. Geological Survey (USGS); $C$, USGS gage on the Roanoke River, taken by Sean Egen, USGS; $D$, fishing boat on the Roanoke Sound, taken by Michelle Moorman. Background image: Currituck Sound, taken by Michelle Moorman. 


\section{Estuarine Monitoring Programs in the Albemarle Sound Study Area, North Carolina}

By Michelle Moorman, Katharine R. Kolb, and Stacy Supak

Prepared in collaboration with the Albemarle-Pamlico National Estuary Partnership as part of the National Monitoring Network for U.S. Coastal Waters and their Tributaries

Open-File Report 2014-1110 


\title{
U.S. Department of the Interior SALLY JEWELL, Secretary
}

\section{U.S. Geological Survey Suzette M. Kimball, Acting Director}

\author{
U.S. Geological Survey, Reston, Virginia: 2014
}

For more information on the USGS — the Federal source for science about the Earth, its natural and living resources, natural hazards, and the environment, visit http://WWW.usgs.gov or call 1-888-ASK-USGS.

For an overview of USGS information products, including maps, imagery, and publications, visit http://WwW.usgs.gov/pubprod

To order this and other USGS information products, visit http://store.usgs.gov

Any use of trade, product, or firm names is for descriptive purposes only and does not imply endorsement by the U.S. Government.

Although this report is in the public domain, permission must be secured from the individual copyright owners to reproduce any copyrighted materials contained within this report.

Suggested citation:

Moorman, M.C., Kolb, K.R., Supak, Stacy, 2014, Estuarine monitoring programs in the Albemarle Sound study area, North Carolina: U.S. Geological Survey Open-File Report 2014-1110, 38 p., http://dx.doi.org/10.3133/ofr20141110. 


\section{Acknowledgments}

We would like to thank all survey participants who returned spreadsheets documenting their projects and monitoring programs. Dean Carpenter, Albemarle-Pamlico National Estuary Partnership (APNEP), was indispensable in helping to coordinate the distribution of the monitoring survey to various stakeholders. Jennifer Dorton, Southeast Coastal Ocean Observing Regional Association (SECOORA), was instrumental in providing information regarding SECOORA activities and the relevance of the National Monitoring Network to SECOORA. 



\section{Contents}

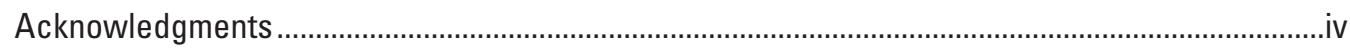

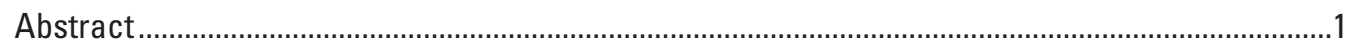

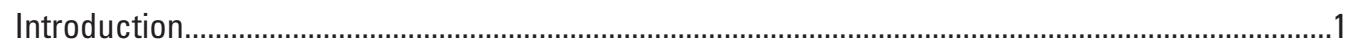

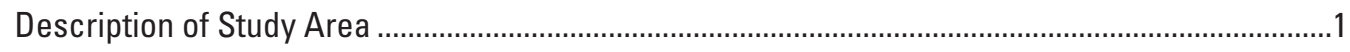

Key Resource Management Agencies .........................................................................................



Impacts of Sea-Level Rise and Extreme Climatic Events......................................................6

Decline of Important Species and Ecosystems .....................................................................6

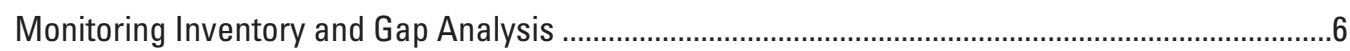

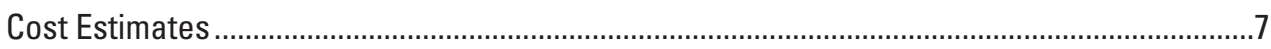

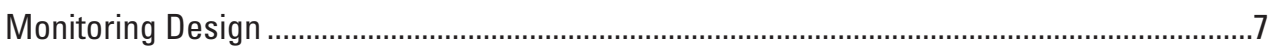

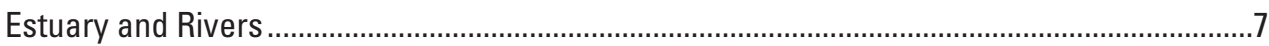

Current Monitoring and Research ............................................................................ 15

Historical Monitoring and Research ......................................................................................18

Monitoring Gaps Identified for Estuary Embayments and Riverine Monitoring..............18

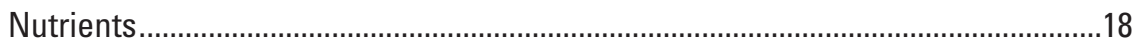

Physical Parameters .............................................................................................. 19

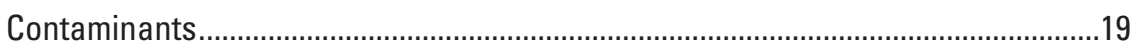

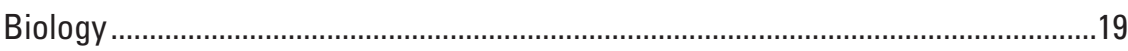

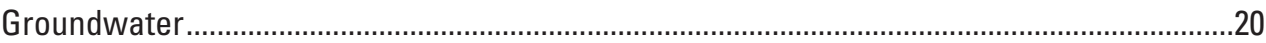

Monitoring Gaps Identified for Groundwater...............................................................20

Atmospheric Deposition ............................................................................................................20

Monitoring Gaps Identified for Atmospheric Deposition .................................................22

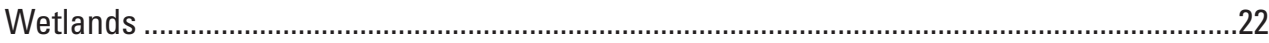

Monitoring Gaps Identified for Wetlands ........................................................................24

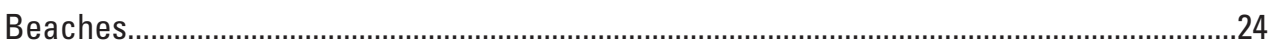

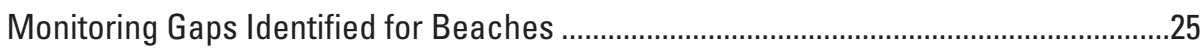

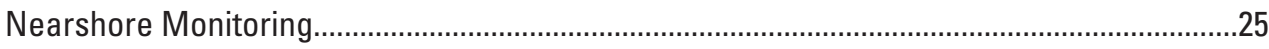

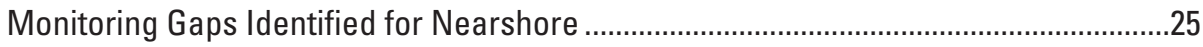

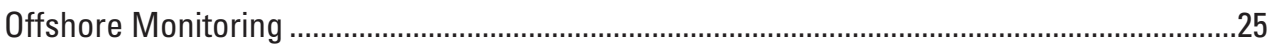

Monitoring Gaps Identified for Offshore .............................................................................22

Relevance of the National Monitoring Network (NMN) to Integrated Ocean Observing

System (IOOS) and Other Regional Monitoring Assessments.....................................27

Data Management and Access Challenges.........................................................................28

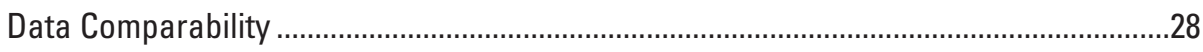

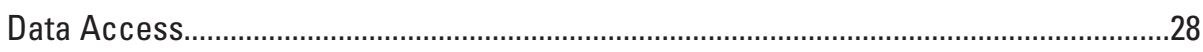

Solutions for Improving Data Access............................................................................28

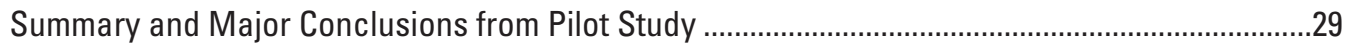

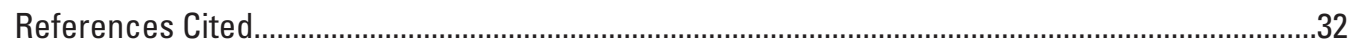

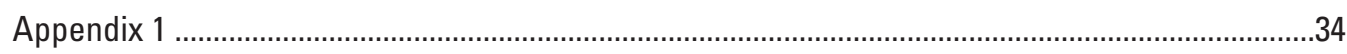

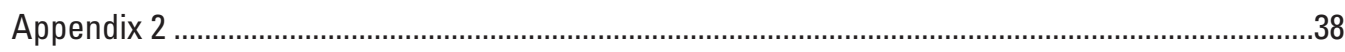




\section{Figures}

1. Map of basins and sub-basins in the Albemarle Sound study area................................ 2

2-11. Maps showing-

2. Albemarle Sound land use/land cover from the National Landcover Dataset, 2006 . . 3

3. Nutrient monitoring in the Albemarle Sound estuary and rivers............................ 14

4. Continuous physical monitoring programs in the Albemarle Sound estuary and rivers................................................................................................ 14

5. Contaminant monitoring in the Albemarle Sound estuary and rivers....................... 15

6. Biological monitoring in the Albemarle Sound estuary and rivers. .......................... 16

7. Groundwater monitoring sites in the Albemarle Sound region................................. 21

8. Atmospheric depositional monitoring in the Albemarle Sound region.................... 22

9. Wetland monitoring in the Albemarle Sound region. ................................................... 23

10. Beach monitoring in the Albermarle Sound region................................................... 24

11. Nearshore and offshore monitoring in the Albemarle Sound region. ...................... 26

\section{Tables}

1. Albemarle-Pamlico National Estuary Partnership management goals, ecosystem outcomes, and candidate indicators. Candidate indicators listed are only a subset of those APNEP candidate ecosystem indicators undergoing evaluation, and do not include candidate stressor or management indicators

2. Inventory of current monitoring in Albemarle Sound: Organizations and summary of program.

3. Inventory of current monitoring in Albemarle Sound: Organizations and resource

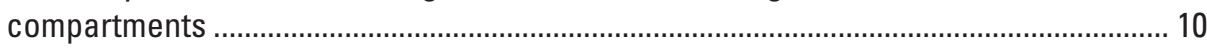

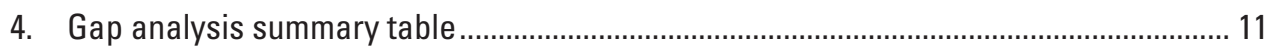

5. Summary of estuarine and riverine monitoring programs .......................................... 12

6. Data access, management and delivery by report name ............................................... 29

7. Recommendations for National Monitoring Network enhancements in the Albemarle Sound region. 


\section{Conversion Factors}

\begin{tabular}{|c|c|c|}
\hline Multiply & By & To obtain \\
\hline \multicolumn{3}{|c|}{ Length } \\
\hline inch (in.) & 2.54 & centimeter $(\mathrm{cm})$ \\
\hline mile (mi) & 1.609 & kilometer (km) \\
\hline mile, nautical (nmi) & 1.852 & kilometer (km) \\
\hline \multicolumn{3}{|c|}{ Area } \\
\hline acre & 0.004047 & square kilometer $\left(\mathrm{km}^{2}\right)$ \\
\hline \multicolumn{3}{|c|}{ Flow rate } \\
\hline cubic foot per second $\left(\mathrm{ft}^{3} / \mathrm{s}\right)$ & 0.02832 & cubic meter per second $\left(\mathrm{m}^{3} / \mathrm{s}\right)$ \\
\hline \multicolumn{3}{|l|}{ SI to Inch/Pound } \\
\hline Multiply & By & To obtain \\
\hline \multicolumn{3}{|c|}{ Length } \\
\hline centimeter $(\mathrm{cm})$ & 0.3937 & inch (in.) \\
\hline kilometer (km) & 0.6214 & mile (mi) \\
\hline \multicolumn{3}{|c|}{ Area } \\
\hline square kilometer $\left(\mathrm{km}^{2}\right)$ & 247.1 & acre \\
\hline square kilometer $\left(\mathrm{km}^{2}\right)$ & 0.3861 & square mile $\left(\mathrm{mi}^{2}\right)$ \\
\hline
\end{tabular}

Temperature in degrees Celsius $\left({ }^{\circ} \mathrm{C}\right)$ may be converted to degrees Fahrenheit $\left({ }^{\circ} \mathrm{F}\right)$ as follows:

${ }^{\circ} \mathrm{F}=\left(1.8 x^{\circ} \mathrm{C}\right)+32$ 
Abbreviations

\begin{tabular}{|c|c|}
\hline ACWI & Advisory Committee on Water Information \\
\hline AMoN & Ammonia Monitoring Network (NADP) \\
\hline AMS & ambient monitoring system \\
\hline APCCAP & Albemarle-Pamlico Climate Change Adaptation Project \\
\hline APNEP & Albemarle-Pamlico National Estuary Partnership \\
\hline CAFO & confined animal feeding operation \\
\hline CEA & coastal ecological assessment \\
\hline CEDS WOM & Comprehensive Environmental Data System Water Quality Monitoring \\
\hline CoCoRaHS & Community Collaborative Rain, Hail, and Snow Network \\
\hline CRONOS & Climate Retrieval and Observations Network of the Southeast \\
\hline CSI & Coastal Studies Institute (UNC) \\
\hline ECU & East Carolina University \\
\hline ENC/SEVA & $\begin{array}{l}\text { Eastern North Carolina/Southeast Virginia Ecoteam } \\
\text { (Department of the Interior) }\end{array}$ \\
\hline ENDS & Exchange Network Discovery Service \\
\hline FRF & (Duck) Field Research Facility (USACE) \\
\hline GSAA & Governors' South Atlantic Alliance \\
\hline GIS & geographic information system \\
\hline HUC & hydrologic unit code \\
\hline I\&M & Inventory and Monitoring \\
\hline IMS & Institute of Marine Science (UNC) \\
\hline IOOS & Integrated Ocean Observing System \\
\hline MACOORA & Mid-Atlantic Coastal Ocean Observing Regional Association \\
\hline MDN & Mercury Deposition Network \\
\hline MDL & method detection limit \\
\hline MDN & Mercury Deposition Network (NADP) \\
\hline NADP & National Atmospheric Deposition Program \\
\hline NARS & National Aquatic Resource Surveys \\
\hline NAWQA & National Water Quality Assessment Program \\
\hline NCA & National Coastal Assessment \\
\hline NCDCM & North Carolina Division of Coastal Management \\
\hline NCDMF & North Carolina Division of Marine Fisheries \\
\hline NCDWR & North Carolina Division of Water Resources \\
\hline NCDWO & North Carolina Division of Water Quality \\
\hline
\end{tabular}




$\begin{array}{ll}\text { NERRS } & \text { National Estuarine Research Reserve System } \\ \text { NMN } & \text { National Monitoring Network } \\ \text { NOAA } & \text { National Oceanic and Atmospheric Administration } \\ \text { NPS } & \text { National Park Service } \\ \text { NRSA } & \text { National Rivers and Streams Assessments } \\ \text { NTN } & \text { National Trends Network } \\ \text { NWIS Web } & \text { National Water Information System Web Interface } \\ \text { NWR } & \text { national wildlife refuge } \\ \text { PRIMR } & \text { Priority Refuge Inventory and Monitoring Report } \\ \text { RL } & \text { reporting limit } \\ \text { SAV } & \text { submerged aquatic vegetation } \\ \text { SECOORA } & \text { Southeast Coastal Ocean Observing Regional Association } \\ \text { ServCat } & \text { Service Catalog } \\ \text { STORET } & \text { STOrage and RETrieval } \\ \text { TNC } & \text { The Nature Conservancy } \\ \text { VADEO } & \text { Virginia Department of Environmental Quality } \\ \text { UNC } & \text { University of North Carolina at Chapel Hill } \\ \text { USACE } & \text { U.S. Army Corps of Engineers } \\ \text { USEPA } & \text { U.S. Environmental Protection Agency } \\ \text { USFS } & \text { U.S. Forest Service } \\ \text { USFWS } & \text { U.S. Fish and Wildlife Service } \\ \text { USGS } & \text { U.S. Geological Survey } \\ \text { VADEO } & \text { Virginia Department of Environmental Quality } \\ \text { WO } & \text { water quality } \\ \text { WOX } & \text { Water Quality Exchange } \\ & \end{array}$




\title{
Estuarine Monitoring Programs in the Albemarle Sound Study Area, North Carolina
}

\author{
By Michelle Moorman, ${ }^{1}$ Katharine R. Kolb, ${ }^{1}$ and Stacy Supak ${ }^{2}$
}

\section{Abstract}

Albemarle Sound was selected in 2012 as one of the two demonstration sites in the Nation to test and improve the design of the National Water Quality Monitoring Council's National Monitoring Network (NMN) for U.S. Coastal Waters and their tributaries. The goal of the NMN for U.S. coastal waters and tributaries is to provide information about the health of our oceans and coastal ecosystems and inland influences on coastal waters for improved resource management. The NMN is an integrated, multidisciplinary, and multiorganizational program using multiple sources of data and information to augment current monitoring programs.

The purpose of this report is to identify major natural resource management issues for the region, provide information on current monitoring activities occurring within the Albemarle Sound study area, determine how the current monitoring network fits into the design of the NMN, and determine what additional monitoring data are needed to address these issues. In order to address these questions, a shapefile and data table were created to document monitoring and research programs in the Albemarle Sound study area with an emphasis on current monitoring programs within the region. This database was queried to determine monitoring gaps that existed in the Albemarle Sound by comparing current monitoring programs with the design indicated by the NMN. The report uses this information to provide recommendations on how monitoring could be improved in the Albemarle Sound study area.

\section{Introduction}

Albemarle Sound was selected in 2012 as one of the two demonstration sites in the Nation to test and improve the design of the National Water Quality Monitoring Council's

${ }^{1}$ U.S. Geological Survey.

${ }^{2}$ North Carolina State University.
National Monitoring Network (NMN) for U.S. Coastal Waters and their Tributaries. The purpose of this report is to identify major natural resource management issues for the region, provide information on current monitoring activities occurring within the Albemarle Sound study area, determine how the current monitoring network fits into the design of the NMN, and determine what additional monitoring data are needed to address these issues.

\section{Description of Study Area}

The Albemarle Sound is part of the Albemarle-Pamlico estuarine system, one of the largest and most important of its kind in the United States. This lagoonal estuarine system has little connection to the Atlantic Ocean because of the chain of barrier islands separating the ocean from the estuary. Albemarle Sound is separated from Pamlico Sound by the Roanoke and Croatan Sounds (fig. 1).

Albemarle Sound and its tributaries form a shallow, low salinity, high turbidity estuary oriented east-west in northeastern North Carolina and southeastern Virginia (fig. 1). The Albemarle Sound covers a surface area of 2,330 square kilometers $\left(\mathrm{km}^{2}\right)$ surrounded by more than 800 kilometers $(\mathrm{km})$ of shoreline. For the purpose of this report, the Albemarle Sound study area has been defined as a region including the Pasquotank, Lower Roanoke, and Chowan River Basins that includes the waters and adjacent wetlands draining into and out of the Albemarle Sound. In addition, the lower portions of the Meherrin, Nottoway, and Blackwater River Basins are included because the majority of the Chowan River is tidally influenced. The precise boundaries of the study area were based on the boundaries of hydrologic units identified by their U.S. Geological Survey (USGS) 12-digit hydrologic unit codes (HUC).

The Albemarle Sound drainage area covers 47,552 $\mathrm{km}^{2}$ and drains the Roanoke, Chowan, and Pasquotank River Basins (inset, fig. 1). The Albemarle Sound study area lies completely within the Coastal Plain of North Carolina and comprises an extensive complex of creeks, rivers, swamps, marshes, and open sound. In their calculations of the annual water 


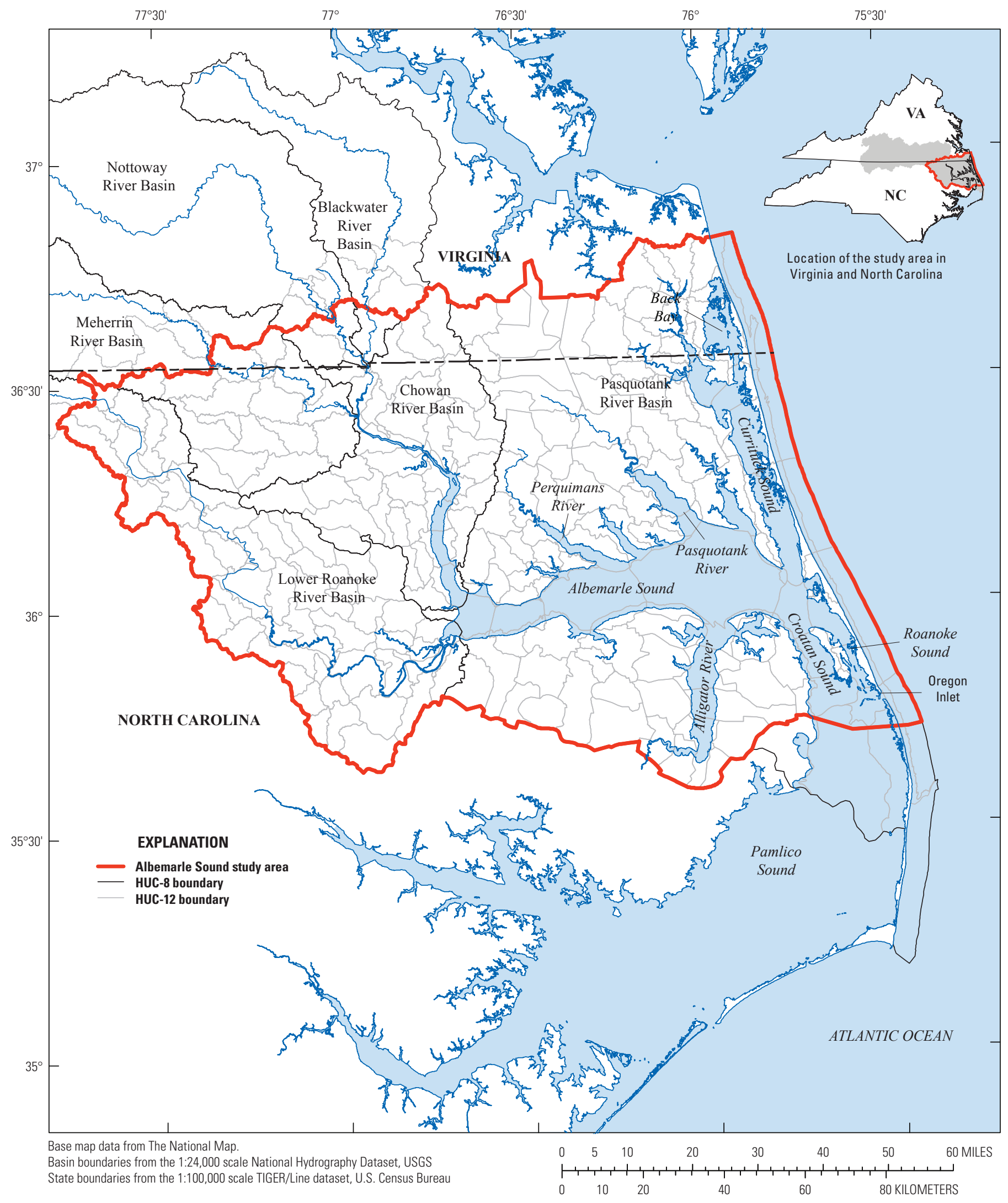

Figure 1. Basins and subbasins in the Albemarle Sound study area. [HUC, Hydrologic Unit Code] 
budget for the Albemarle Sound, Giese and others (1985) computed an average of 17,000 cubic feet per second $\left(\mathrm{ft}^{3} / \mathrm{s}\right)$ of water entering the Albemarle Sound at any given point in time. Although runoff and precipitation vary seasonally, annual mean flow estimates based on discharge data from streamgages suggest on the Roanoke River and Chowan River contribute 8,900 and $4,600 \mathrm{ft}^{3} / \mathrm{s}$, respectively. Other smaller rivers and tidal creeks drain coastal-area swamps, including the Perquimans, Little, Pasquotank, and North Rivers in the northern part of the Albemarle Sound and the Scuppernong and Alligator Rivers in the southern part of the sound, but they only account for a quarter (approximately $2,900 \mathrm{ft}^{3} / \mathrm{s}$ ) of the total freshwater inflow to the sound. An additional 3,400 ft $\mathrm{ft}^{3} / \mathrm{s}$ of water is contributed by precipitation. Although the Giese and others (1985) study is nearly 30 years old, it is still the most current, and uses streamgage data with periods of records for some sites dating back to the 1920s. The approximate residence time of water in the sound is 45 days because there is no direct connection to, and little exchange with, the ocean due to the barrier islands that bound the eastern portion of the study area, separating the sound from the ocean (Giese and others, 1985). Because there is little tidal exchange between the Albemarle Sound and Oregon Inlet, wind-driven tides are the major driver of water movement in the Albemarle Sound, with southwesterly winds predominating except during major storm events.
The climate for the region is relatively mild, with mean winter temperatures ranging between 6 and $8{ }^{\circ} \mathrm{C}$ and mean summer temperatures often exceeding $32{ }^{\circ} \mathrm{C}$. Mean annual precipitation in the study area ranges from 111 to 137 centimeters per year (cm/yr, PRISM, 2012). There is little seasonal variation in rainfall, but the amount can vary substantially between dry years, when total precipitation can be less than 89 centimeters $(\mathrm{cm})$, and wet years, when total precipitation can exceed $200 \mathrm{~cm}$ (Carpenter and Dubbs, 2012).

The Albemarle Sound study area's geography is predominantly rural, with a population of 511,479 and few urban areas, except for tourism-related development near the coast along the barrier islands and City of Virginia Beach suburbs. According to the National Land Cover Database 2006, 28.1 percent was wetland; 24.1 percent was cropland; 15.1 percent was forested; 21.2 percent was open water; 6.4 percent was barren, shrub/scrub, or grassland; and 5.2 percent of the land in the study area was classified as urban in 2006 (fig. 2; Fry and others, 2011). Prior to settlement, much of the land consisted of peat wetlands known as pocosins. Most of these pocosins have been ditched and drained to allow agricultural and silvicultural activities. In general, there has been a decline in the extent of forests and wetlands in the area during the past 20 years (Carpenter and Dubbs, 2012, p. 45-53).

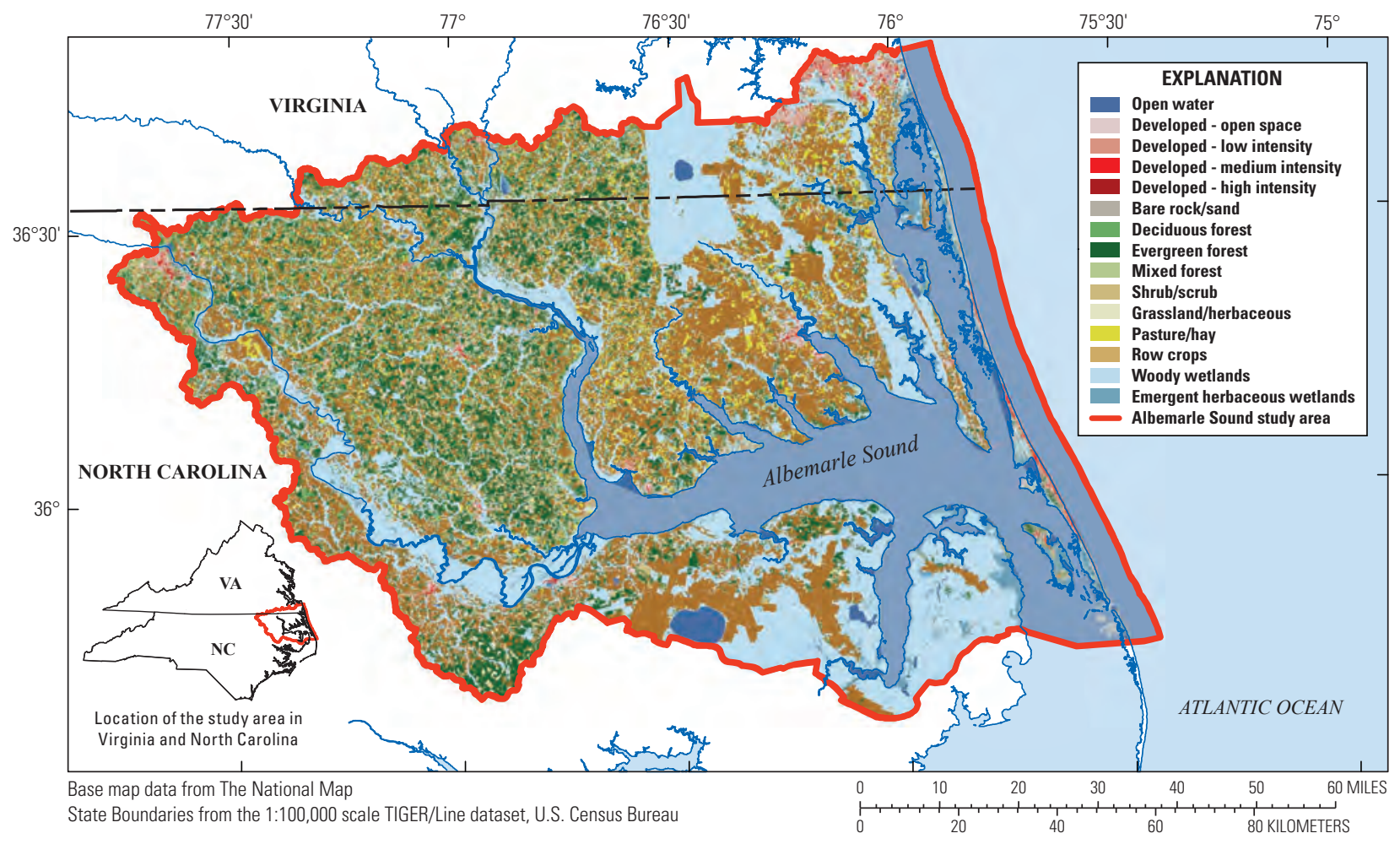

Figure 2. Albemarle Sound land use/land cover from the National Landcover Dataset, 2006. 


\section{Key Resource Management Agencies}

The principal management agencies responsible for maintaining and improving environmental resources in the Albemarle Sound study region are the North Carolina Department of Environment and Natural Resources, which includes the Albemarle-Pamlico National Estuary Partnership (APNEP); the North Carolina Division of Coastal Management (NCDCM); the North Carolina Division of Marine Fisheries (NCDMF); the North Carolina Division of Parks and Recreation; the North Carolina Division of Water Resources (NCDWR); the North Carolina Forest Service; the North Carolina Wildlife Resources Commission; the Virginia Department of Environmental Quality (VADEQ), which includes the Virginia Department of Game and Inland Fisheries, Virginia Department of Forestry, and Virginia Department of Conservation and Recreation; the U.S. Department of the Interior, which includes the U.S. Fish and Wildlife Service (USFWS) and National Park Service (NPS); and the U.S. Environmental Protection Agency (USEPA). Four of these agencies, APNEP, NCDMF, NCDWR, and USFWS, have either recently published, or are in the process of publishing, management plans for the region. These plans help to identify important resources in the sound, threats and stressors to these resources, and strategies needed for protecting the resources. All of these management plans identify monitoring as an important component of resource management.

APNEP includes partners from various academic, governmental, nonprofit, and private organizations to articulate and address major management issues for the Albemarle-Pamlico Sound. In 2012, APNEP updated their 1994 Comprehensive Conservation and Management Plan based on input from their partners (APNEP, 2012). This plan designates goals, outcomes, actions, and objectives for the estuarine systems. Major management goals listed in the plan include sustaining human communities, native species, and water quality and quantity within the region. Table 1 lists how various ecosystem outcomes relate to these management goals and suggested candidate indicators for measuring the success of the targeted outcomes in the estuarine system.

The NCDMF has extensive documentation on management issues of concern for marine fisheries in their Coastal Habitat Protection Plan (Deaton and others, 2010). NCDMF's primary concern is maintaining and improving important commercial and recreational fisheries in North Carolina. This includes insuring adequate water quality, especially in designated anadromous fish spawning areas, and protecting and restoring important fishery habitats such as oyster reefs and submerged aquatic vegetation (SAV) beds. The Coastal Habitat Protection Plan compiles information on the environmental requirements, spatial distribution, ecological value, overall condition, and threats to coastal fish habitats and ecosystems. Major management goals of the Coastal Habitat Protection Plan include the following:
- Improve effectiveness of existing rules and programs protecting fish habitats

- Identify, designate, and protect strategic habitat areas

- Enhance habitat and protect it from physical impacts

- Enhance and protect water quality

The plan also identifies research and monitoring needs for the sound.

The NCDWR publishes water quality plans for the Pasquotank, Roanoke, and Chowan River Basins. Reports are published once every 5 years and document the condition of water quality in each basin and the status of current restoration and conservation initiatives in the basin. All plans are available at $h t t p: / / p o r t a l . n c d e n r . o r g / w e b / w q / p s / b p u / b a s i n$. In addition, NCDWR has been working on a nutrient criteria development plan to address the State's ability to control nutrient overenrichment. The plan will collaboratively highlight and enhance North Carolina's current approaches to nutrient management, provide for site- and waterbody-specific approaches, and provide for built-in protection and prevention (NCDENR, 2014). More information about the plan is available at http://portal.ncdenr.org/web/wq/ps/mtu/nutrientcriteria.

The USFWS manages eight refuges in the Albemarle Sound study area and two additional wildlife refuges on the Albemarle Sound Peninsula, and the NPS manages Cape Hatteras National Seashore. Currently, the USFWS is leading a conservation planning process for the Eastern North Carolina/ Southeast Virginia Ecoteam (ENC/SEVA), a collaborative group composed of different Department of the Interior agencies and partners that manage lands and conduct science in the region. The ENC/SEVA's mission is to develop a Strategic Habitat Conservation Plan for the purpose of improving landscape-level conservation within the geographic region. The plan provides guidance to ENC/SEVA members, partners, and collaborators by establishing mutual conservation goals, objectives, and strategies as well as metrics to gauge the success of conservation efforts across the region (USFWS, 2008). In addition, the plan identifies research needs, knowledge gaps, and conservation priorities and prioritizes threats to the ecological integrity of the system. For the Albemarle Sound study area, the conservation and protection of submerged aquatic vegetation, areas with natural shorelines, estuarine wetlands, and estuarine-dependent species were identified as conservation priorities for the estuarine system by ENC/SEVA (Louise Alexander, written commun., 2013).

\section{Major Natural-Resource Issues}

The conservation planning processes being undertaken by APNEP, NCDMF, NCDWR, and ENC/SEVA help to identify and prioritize major natural resource management issues for the area. Each of these organizations has invested a great amount of time and effort in this process. Three management goals given 
Table 1. Albemarle-Pamlico National Estuary Partnership (APNEP) management goals, ecosystem outcomes, and candidate indicators.

[Candidate indicators listed are only a subset of those APNEP candidate ecosystem indicators undergoing evaluation and do not include candidate stressor or management indicators]

\begin{tabular}{|c|c|c|}
\hline \multirow{3}{*}{$\begin{array}{l}\text { Human communities: A region where human } \\
\text { communities are sustained by ecosystem } \\
\text { function }\end{array}$} & Waters are safe for personal contact. & Beach closings \\
\hline & Fish and game are safe for human consumption. & $\begin{array}{l}\text { Fish consumption advisories and } \\
\text { shellfish area closures }\end{array}$ \\
\hline & $\begin{array}{l}\text { Opportunities for recreation and access to public } \\
\text { lands and waters are protected and enhanced. }\end{array}$ & $\begin{array}{l}\text { Water access points and land/paddle } \\
\text { trails }\end{array}$ \\
\hline \multirow[t]{2}{*}{$\begin{array}{l}\text { Native species: A region where aquatic, } \\
\text { wetland, and upland habitats support } \\
\text { viable populations of native species }\end{array}$} & $\begin{array}{l}\text { The extent and quality of upland, freshwater, } \\
\text { estuarine and nearshore marine habitats fully } \\
\text { support biodiversity and ecosystem function. }\end{array}$ & $\begin{array}{l}\text { Submerged aquatic vegetation extent } \\
\text { and anadromous fish spawning and } \\
\text { nursery areas }\end{array}$ \\
\hline & $\begin{array}{l}\text { Non-native invasive species do not significantly } \\
\text { impair native species' viability or function, nor } \\
\text { impair habitat quality, quantity, and the } \\
\text { processes that form and maintain habitats. }\end{array}$ & Extent and status of invasive species \\
\hline $\begin{array}{l}\text { Water quality and quantity: A region where } \\
\text { water quantity and quality maintain } \\
\text { ecological integrity }\end{array}$ & $\begin{array}{l}\text { Sediments do not harm species that depend on the } \\
\text { waters. }\end{array}$ & $\begin{array}{l}\text { Amount and extent of imparied waters, } \\
\text { average secchi depth }\end{array}$ \\
\hline
\end{tabular}


a high priority by each organization include (1) managing for sea-level rise and its associated impacts on coastal communities and natural resources, (2) insuring the estuary remains a healthy and productive ecosystem that can support important estuarinedependent species, and (3) protecting important estuarine habitat including SAV and wetlands.

\section{Impacts of Sea-Level Rise and Extreme Climatic Events}

Several recent studies have shown that the mid-Atlantic region is an area experiencing accelerated relative sea-level rise. This rise has been linked to numerous factors, including climate change, a slowdown of the Gulf Stream, and local land subsidence (Boon, 2012; Sallenger and others, 2012; Ezer and others, 2013). The negative impacts of sea-level rise may intensify other coastal hazards, such as flooding, storm surge, shoreline erosion, eutrophication, and shoreline recession, especially during extreme climatic events. Sea-level rise and extreme climatic events can also threaten freshwater resources and quality, private property and development, tourism and economic vitality, historic and cultural resources, agriculture, forestry, and public property and infrastructure. Coastal managers need accurate information about the potential effects of future sea-level rise and extreme climatic events to help plan and prepare for them.

\section{Decline of Important Species and Ecosystems}

Natural resource managers are particularly concerned with the management of ecosystems, including the species dependent on these ecosystems. Estuarine habitats and estuarine-dependent species can be negatively impacted by a variety of anthropogenic activities that cause their degradation, including pollution from nutrients and other sources and the loss of important estuarine and shoreline vegetation. Widespread nutrient enrichment has been observed in surface waters across the Nation (Bricker and others, 2007; Environmental Protection Agency, 2009) and often leads to taste and odor issues in drinking water supplies, increased treatment costs for drinking water, toxic algal blooms, oxygen depletion, fish kills, decreases in the aesthetic value of the source-water bodies, and an overall decline in ecosystem health. The loss of shoreline vegetation can make shorelines more susceptible to erosion, cause an increase in the direct inputs of sediment and nutrients to the estuary due to the loss of the vegetative buffer, and reduce the availability of primary nursery grounds for fish (Currin and others, 2010).

SAV consists of vascular plants that provide important ecosystem functions, such as improving estuarine water quality by removing suspended solids from the water, adding dissolved oxygen to the water, and utilizing available nutrients. SAV provides important refuge for fish and invertebrates and an important food source to many species of waterfowl. In addition, SAV indicates (and helps maintain) good water quality. Mapping estimates suggest there are over 21,577 acres of suitable SAV habitat in the Albemarle Sound (Deaton and others, 2010; Carpenter and Dubbs, 2012, p. 124-128). The distribution of SAV beds in the estuarine system is controlled by water depth, sediment composition, current and wave energy, and light availability. The extent of SAV loss has not been well quantified in North Carolina, but anecdotal reports indicate SAV beds may be reduced by as much as 50 percent, especially on the mainland side of coastal sounds (North Carolina Sea Grant, 1997). The majority of SAV loss can be attributed to the reduction of light availability because of sedimentation and excess algal growth associated with nutrient enrichment. Thus, there is a need to better understand the waterquality conditions necessary for promoting healthy SAV populations in North Carolina and to determine areas within the sounds that support these conditions.

Commercial and recreational fishing are important economic activities in the Albemarle Sound. Several species of anadromous fish, including striped bass (Morone saxatilis Walbaum), alewife (Alosa pseudoharengus Wilson), and blueback herring (Alosa aestivalis Mitchill), along with blue crab (Callinectes sapidus Rathbun), are important both commercially and recreationally, and depend on habitat in the sound for their survival. Importantly, portions of Albemarle Sound and Chowan and Roanoke Rivers were recently nominated by the NCDMF as strategic habitat areas (Deaton and others, 2010). They identified spawning and nursery areas for anadromous fish species and shallow sound shorelines used as fish and blue crab nurseries. This nomination was driven by concern about sharp declines in river herring (specifically, alewife and blueback herring) stocks that triggered a fishing moratorium in 2007 (Carpenter and Dubbs, 2012, p. 91-103). The exact cause of the fishery declines is unknown, but could be attributed to many factors, including predation, by-catch, poor water quality, degradation of critical habitat areas, barriers to historic spawning areas, or loss of juveniles from industrial, municipal, and agricultural water use.

\section{Monitoring Inventory and Gap Analysis}

The Albemarle Sound Demonstration Study inventory documents monitoring programs and studies in the region. All of the management and monitoring agencies included in the inventory have determined that a comprehensive assessment of monitoring programs in the region would help improve understanding and management of Albemarle Sound resources. In 2012, an inventory of current and 
recent monitoring programs and studies in the Albemarle Sound study region was completed. The USGS partnered with APNEP to distribute a spreadsheet designed to capture program information, including sample design and monitoring locations from individual organizations working in the region. Spreadsheets were returned to the USGS and compiled into a spatial database of individual monitoring sites (AlbeMonProg13.zip) that can be joined to a data table that documents the monitoring program (AlbeMonTable2013.dbf) and is available at http://dx.doi.org/10.3133/ofr 2014110 . The data table of monitoring activities can also be viewed and queried in Microsoft Excel (AlbeMonTable2013.xlsx, table fields mentioned herein are underlined). In total, the data table documents 149 sample designs ( $\underline{\text { SampName }}$ ) that are used to collect data for the 107 monitoring programs and studies captured ( $\underline{\text { ProgName }}$ ) by this initiative. If spatial data documenting monitoring locations were provided, the sample design has a unique identifier ( $\underline{\text { SampNo }})$ that directly relates to one of the 8,808 locational data points provided by stakeholders through a one-to-many relationship.

The reporting organizations (RepOrg) provided information about their various monitoring and research programs and have been classified into 20 unique umbrella organizations. Of the 107 monitoring programs, 63 were classified

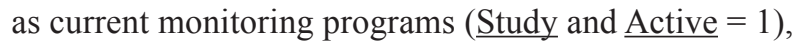
18 were classified as current research studies, and 26 were classified as recently discontinued monitoring and research programs $(\underline{\text { Active }}=0)$. Table 2 provides a summary of current monitoring projects by reporting organization, although some projects having similar sample designs within the same umbrella organization have been lumped for brevity within the RepName field.

Every effort was made through collaboration with APNEP to thoroughly document all current monitoring programs in the study area. All information in the database is based on stakeholder input, thus some monitoring and research programs may not be documented if no information was provided or no information was readily available on the Web that allowed us to generate a record for the monitoring and research program. We believe most current monitoring programs have been captured in the database, but records are incomplete for research programs and historic monitoring programs. This database could easily be updated in the future to incorporate new monitoring and research programs and further document historic programs.

\section{Cost Estimates}

Few agencies reported the costs of their current monitoring programs. When reported, monitoring costs varied significantly between agencies because of varying accounting methods; specifically, not all agencies include salaries or analytical costs in their monitoring costs. For this reason, we could not accurately estimate current monitoring costs in the Albemarle Sound study region.

\section{Monitoring Design}

The design of the NMN suggests that the monitoring program will be a "network of networks," meaning that many existing monitoring programs will help meet the monitoring needs of the NMN. For the purpose of this report, the focus is on current monitoring and research programs in the Albemarle Sound. As outlined in the design of the NMN, the effort of each monitoring organization was collated by the nine resource compartments ( $\underline{\text { ResComp }}$ ) specified by the NMN: estuary embayment, rivers, nearshore, offshore, groundwater, atmospheric deposition, wetlands, and beaches (table 3). Current monitoring programs were compared with the idealized design of the NMN to identify monitoring gaps (ACWI and NWQMC, 2006).

The sampling programs within each resource compartment were synthesized by relevant parameter groups, including nutrients ( $\underline{\text { NutSamp}})$, contaminants ( $\underline{\text { ContSamp }), ~ b i o l o g y ~}$

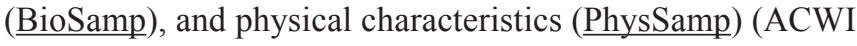
and NWQMC, 2006). The data dictionary for the shapefile specifies the parameter group assigned to each specific parameter (appendix 1). The following sections contain detailed descriptions of each organization's monitoring program, by resource compartment, including a list of the parameters sampled, a description of how frequently and how many sites are sampled, maps of monitoring locations, and information about data storage and access, including links to any online databases. The entry for the RepName field for each program is bolded (typically in parentheses) following each program in the following sections and used to identify individual monitoring sites for the program in the accompanying figures. The specific database queries used to select monitoring programs sampling each selected parameter groups for each resource compartment are available in appendix 2. Network gaps are identified and discussed for each compartment. From this information, estimates of the percentage of ongoing monitoring that completed the NMN design goals for each of the major parameters groups in water and sediment were made (table 4). Table 4 also provides estimates of the number of sites with no ongoing monitoring that need to increase the frequency at which they are sampled or that need to add additional analytes for each resource compartment.

\section{Estuary and Rivers}

Several organizations monitor water and sediment of both the Albemarle Sound estuary and its tributaries (table 3). Program elements, including analytes for each parameter group (that is, nutrients, physical characteristics, contaminants, or biology), number of sites, and frequency of monitoring are summarized in table 5. More detailed program descriptions by organization are provided below. This information can be used to better interpret the maps showing monitoring site locations measuring nutrients, continuous physical parameters, contaminants, and biology (figs. 3-6). 
Table 2. Federal and non-Federal monitoring programs active within the Albemarle Sound region.

[U.S., United States; N.C., North Carolina]

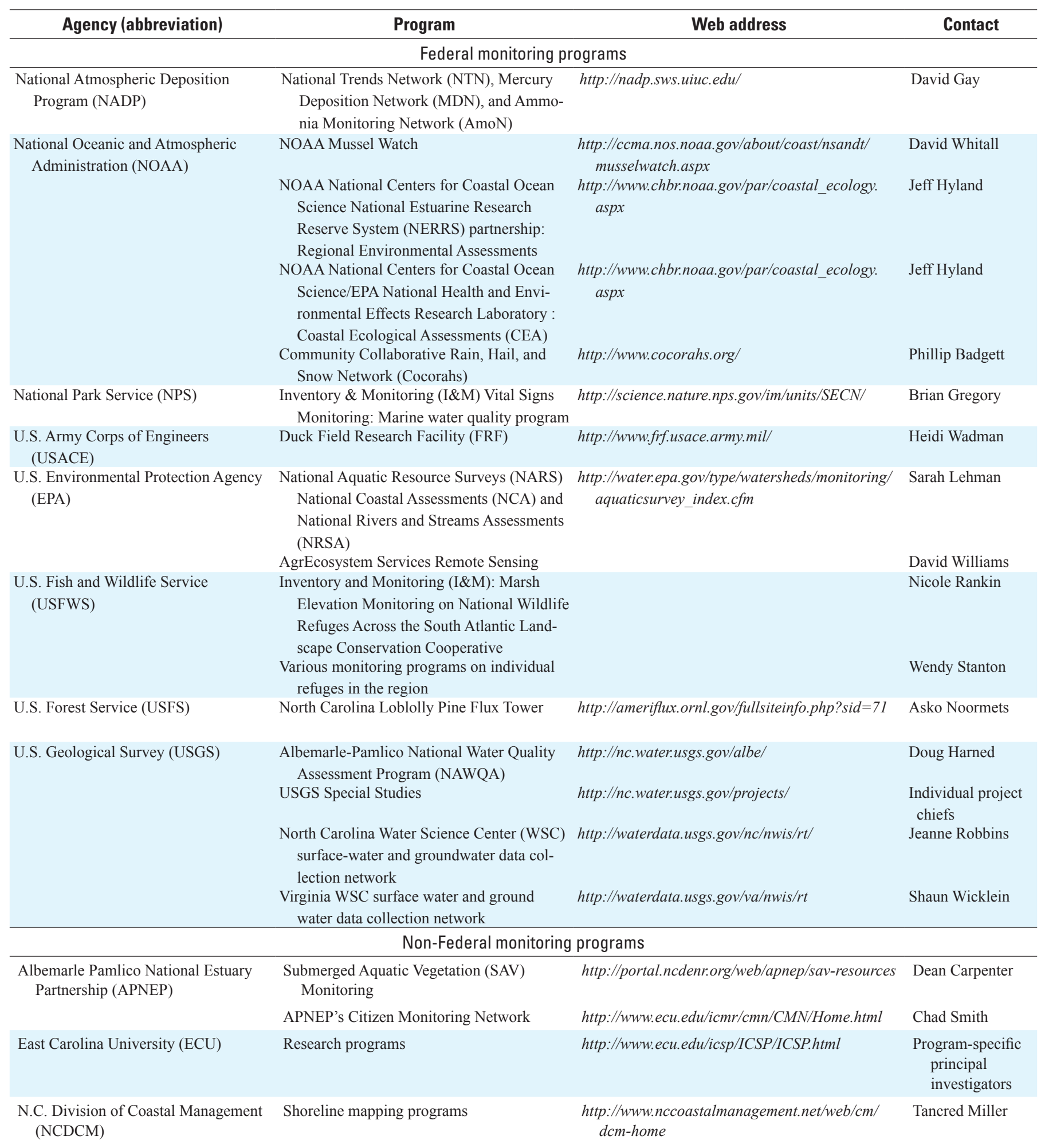


Table 2. Federal and non-Federal monitoring programs active within the Albemarle Sound region.-Continued

[U.S., United States; N.C., North Carolina]

\begin{tabular}{|c|c|c|c|}
\hline Agency (abbreviation) & Program & Web address & Contact \\
\hline \multirow[t]{2}{*}{$\begin{array}{l}\text { N.C. Division of Marine Fisheries } \\
\text { (NCDMF) }\end{array}$} & $\begin{array}{l}\text { N.C. Shellfish Sanitation and Recreational } \\
\text { Water Quality Monitoring Programs }\end{array}$ & $\begin{array}{l}\text { http://portal.ncdenr.org/web/mf/shellfish- } \\
\text { sanitation-and-recreational-water-quality }\end{array}$ & Shannon Jenkins \\
\hline & Fishery Monitoring Programs & & Kathy Rawls \\
\hline $\begin{array}{l}\text { N.C. Division of Water Quality } \\
\text { (NCDWQ) }\end{array}$ & Ambient Monitoring System (AMS) & http://portal.ncdenr.org/web/wq/ess/eco/ams & Steven Kroeger \\
\hline N.C. State Climate Office & CRONOS (climate database) & http://www.nc-climate.ncsu.edu/econet & $\begin{array}{l}\text { Program-specific } \\
\text { principal } \\
\text { investigators }\end{array}$ \\
\hline $\begin{array}{l}\text { N.C. Division of Water Resources } \\
\text { (NCDWR) }\end{array}$ & Ground Water Monitoring & http://www.ncwater.org/?page $=3$ & Nat Wilson \\
\hline N.C. Sea Grant & Pre-storm deployed wave gages & http://www.ncseagrant.org/ & Spencer Rogers \\
\hline The Nature Conservancy (TNC) & $\begin{array}{l}\text { Albemarle-Pamlico Climate Change Adap- } \\
\text { tation Project (APCCAP) }\end{array}$ & & Christine Pickens \\
\hline $\begin{array}{l}\text { University of North Carolina Institute } \\
\text { of Marine Sciences (UNC-IMS) }\end{array}$ & Research programs & http://ims.unc.edu/ & $\begin{array}{l}\text { Program-specific } \\
\text { principal } \\
\text { investigators }\end{array}$ \\
\hline \multirow[t]{2}{*}{$\begin{array}{l}\text { Virginia Department of Environmental } \\
\text { Quality (VADEQ) }\end{array}$} & Trend Network & $\begin{array}{l}\text { http://www.deq.virginia.gov/Programs/Water/ } \\
\text { WaterQualityInformationTMDLs/WaterQuali- } \\
\text { tyMonitoring.aspx }\end{array}$ & Don Smith \\
\hline & Probablistic Network & $\begin{array}{l}\text { http://www.deq.virginia.gov/Programs/Water/ } \\
\text { WaterQualityInformationTMDLs/WaterQuali- } \\
\text { tyMonitoring.aspx }\end{array}$ & Don Smith \\
\hline WeatherFlow & Private Weather Monitoring Network & $\begin{array}{l}\text { http://www.weatherflow.com/coastal-weather- } \\
\text { networks/the-weatherflow-coastal-mesonet/ }\end{array}$ & Steve Woll \\
\hline
\end{tabular}


Table 3. Inventory of current monitoring in Albemarle Sound: Organizations and resource compartments.

$\left[++\right.$, major monitoring effort ${ }^{1} ;+$, minor monitoring effort ${ }^{1}$; blank cell, no current monitoring effort documented ${ }^{2}$; APNEP, Albemarle-Pamlico National Estuary Partnership; Cocorahs, Community Collaborative Rain, Hail, and Snow Network; CSI, Coastal Studies Institute ; ECU, East Carolina University; EPA, Environmental Protection Agency; IMS, Institute of Marine Science (UNC); N.C., North Carolina; NADP, National Atmospheric Deposition Program; NCDCM, North Carolina Division of Coastal Management; NCDMF, North Carolina Division of Marine Fisheries; NCDWR, North Carolina Division of Water Resources; NCSU, North Carolina State University; NOAA, National Oceanic and Atmospheric Administration; NPS, National Park Service; TNC, The Nature Conservancy; VADEQ, Virginia Department of Environmental Quality; USACE, U.S. Army Corps of Engineers; USFS, U.S. Forest Service; USFWS, U.S. Fish and Wildlife Service; USGS, U.S. Geological Survey; VADEQ, Viginia Department of Environmental Quality]

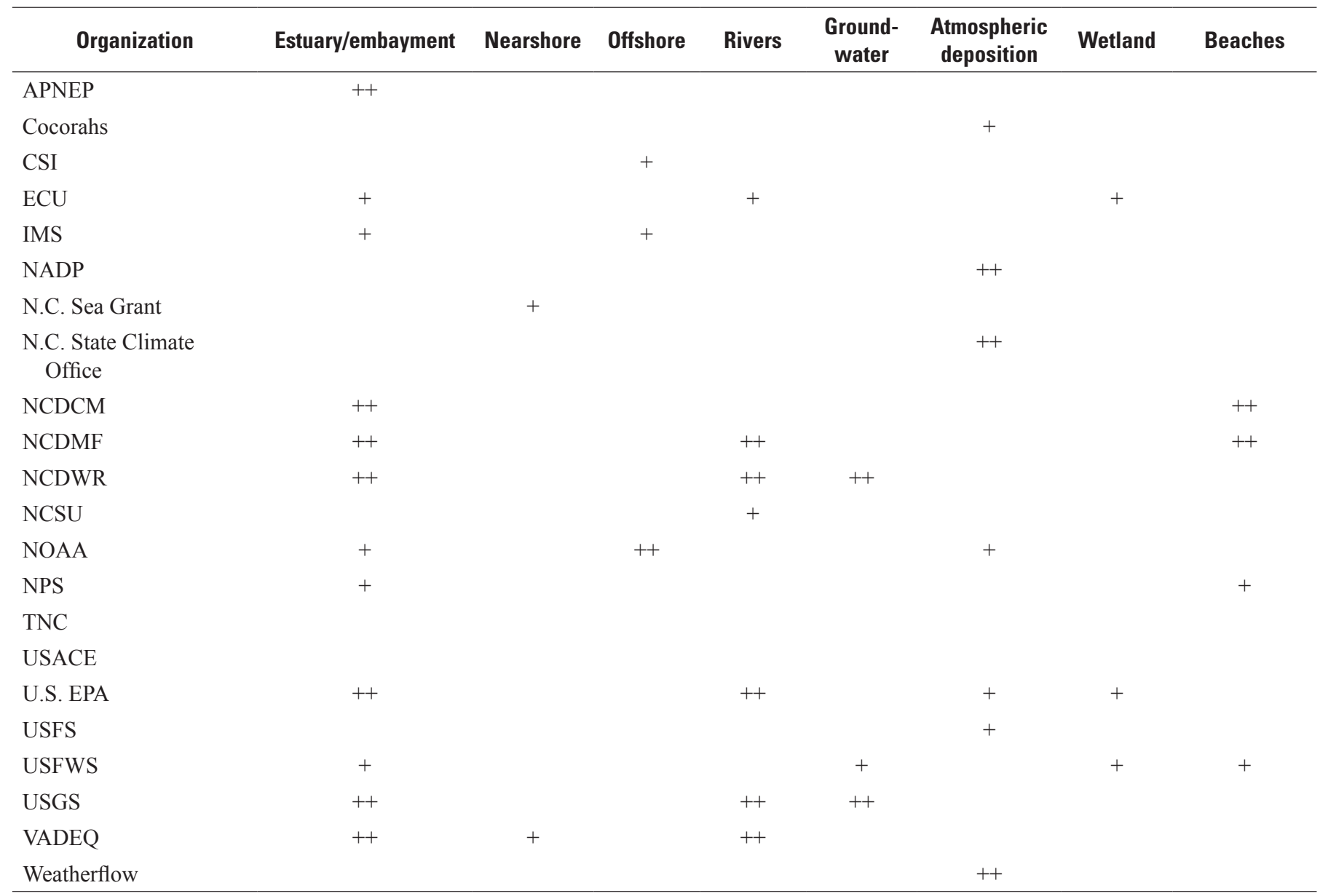

${ }^{1}$ Decisions about whether monitoring efforts are major or minor were based on two factors: duration and geographic extent. If an organization is making a major effort for both factors, it was judged to be a major effort overall. If an organization has a major effort underway for only one factor, it was judged to be a minor effort overall. Similarly, if an organization has a minor effort underway for both factors, it was judged to be a minor effort overall. The following guidelines are used to determine whether monitoring efforts were major or minor for each compartment:

Duration-Major is three or more years of ongoing monitoring (Monitor $=1$ in database). Minor is less than three years in duration (Study $=1$ in database). The table is intended to show current efforts; thus, organizations that conducted monitoring at some point in the past but that are no longer active were judged to be not applicable and left blank for that component in the table.

Geographic extent-Major indicates that an organization uses standard procedures and protocols over large areas such as (1) $50 \%$ or more of a Network estuary; or (2) measurement of rivers at the drainage point of HUC-6 or other important river; or (3) major aquifers in the study area. Minor indicates specific studies in smaller portions of the study area. For example, research studies focused on a few sites would be minor in geographic extent.

${ }^{2}$ An organization was judged to be not applicable and component columns left blank if there are no current monitoring efforts for that resource compartment. 

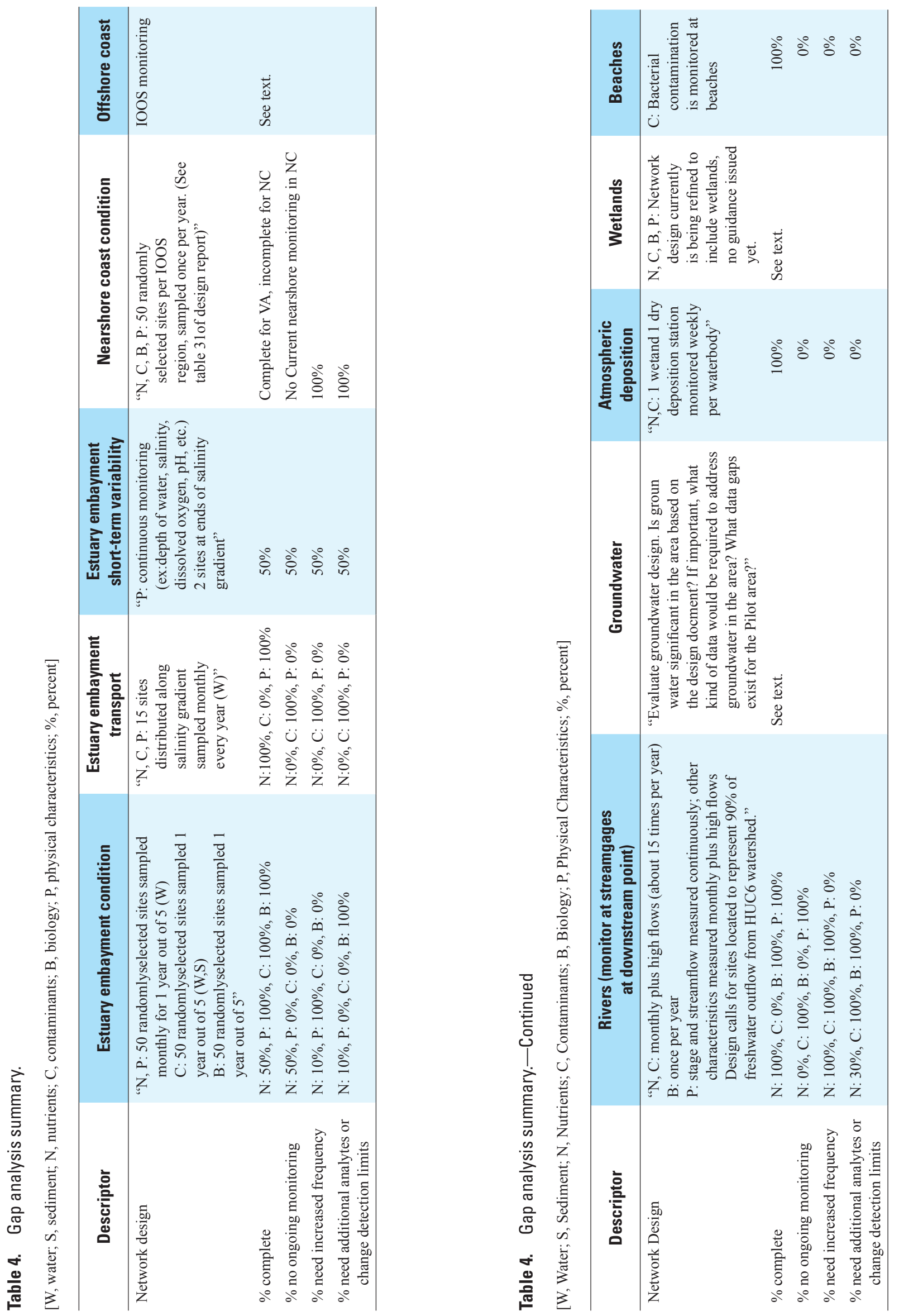
Table 5. Summary of estuarine and riverine monitoring programs.

[AMS, ambient monitoring system; APNEP, Albemarle-Pamlico National Estuary Partnership; CAFO, confined animal feeding operations; chl a, chloro-phyll $a$; DO, dissolved oxygen; EPA, Environmental Protection Agency; I\&M, Inventory and Monitoring; NARS, National Aquatic Resource Surveys; NCA, National Coastal Assessment; NCDMF, North Carolina Division of Marine Fisheries; NCDWQ, North Carolina Division of Water Quality; NOAA, National Oceanic and Atmospheric Administration; NPS, National Park Service; NRSA, National Rivers and Streams Assessment; PAR, photosynthetically available radiation; PAH polycyclic aromatic hydrocarbons; PCB polychlorinated biphenyl; PIC, particulate inorganic carbon; POC, particulate organic carbon; TDP total dissolved phosphorus; TDN total dissolved nitrogen; TKN totak Kjeldahl nitrogen; TP total phosphorus; TSS total suspended solids; TOCtotal organic carbon; USACE, U.S. Army Corps of Engineers; USGS, U.S. Geological Survey; VADEQ, Viginia Department of Environmental Quality; WQ, water quality]

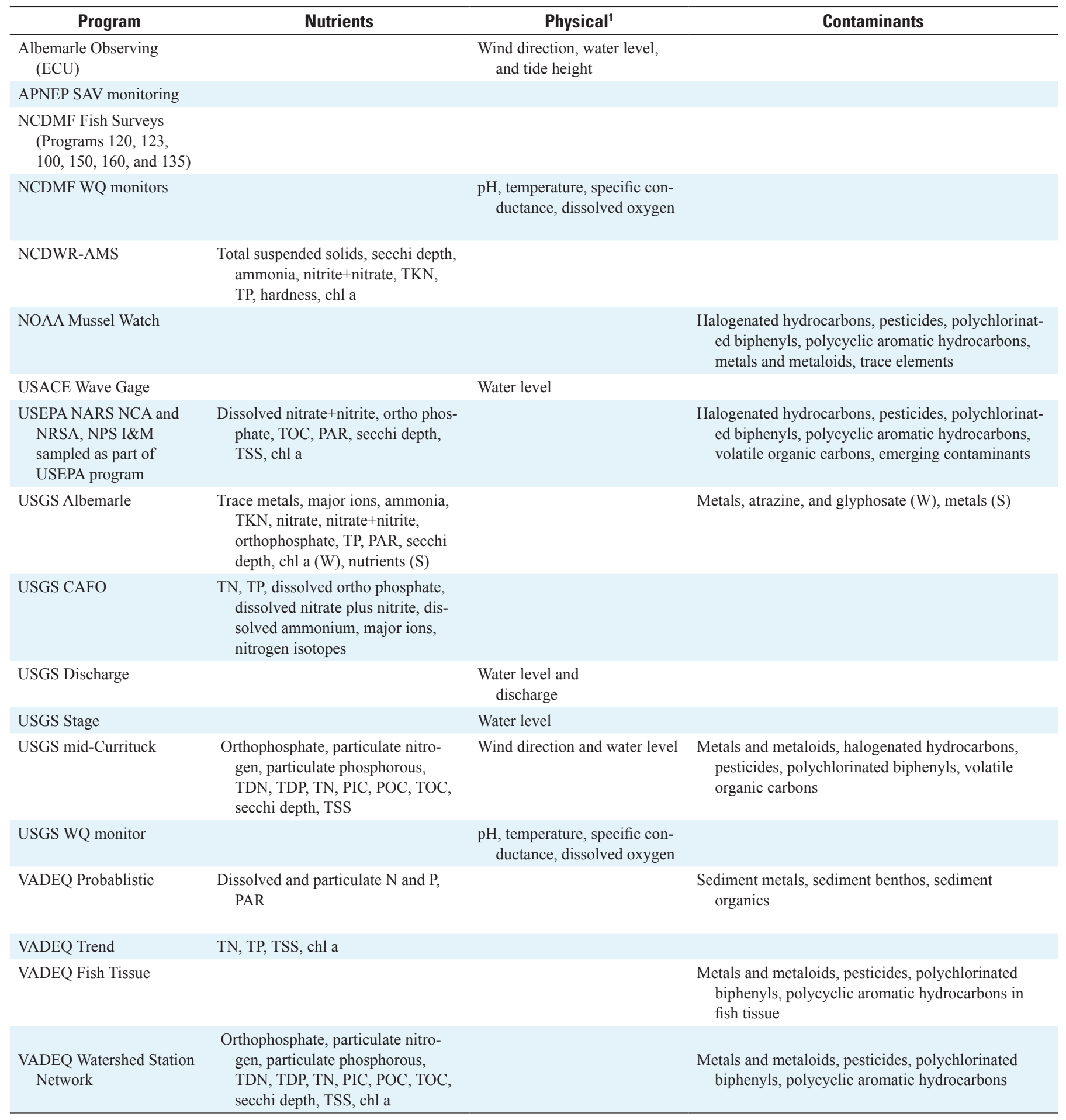

\footnotetext{
${ }^{1}$ Most programs take discrete physical measurements ( $\mathrm{pH}$, Temp, DO, Specific Conductance) as part of their routine monitoring program. Only continuously monitored parameters are noted here.
} 
Table 5. Summary of estuarine and riverine monitoring programs. - Continued

[AMS, ambient monitoring system; APNEP, Albemarle-Pamlico National Estuary Partnership; CAFO, confined animal feeding operations; chl a, chloro-phyll $a$; DO, dissolved oxygen; EPA, Environmental Protection Agency; I\&M, Inventory and Monitoring; NARS, National Aquatic Resource Surveys; NCA, National Coastal Assessment; NCDMF, North Carolina Division of Marine Fisheries; NCDWQ, North Carolina Division of Water Quality; NOAA, National Oceanic and Atmospheric Administration; NPS, National Park Service; NRSA, National Rivers and Streams Assessment; PAR, photosynthetically available radiation; PAH polycyclic aromatic hydrocarbons; PCB polychlorinated biphenyl; PIC, particulate inorganic carbon; POC, particulate organic carbon; TDP total dissolved phosphorus; TDN total dissolved nitrogen; TKN totak Kjeldahl nitrogen; TP total phosphorus; TSS total suspended solids; TOCtotal organic carbon; USACE, U.S. Army Corps of Engineers; USGS, U.S. Geological Survey; VADEQ, Viginia Department of Environmental Quality; WQ, water quality]

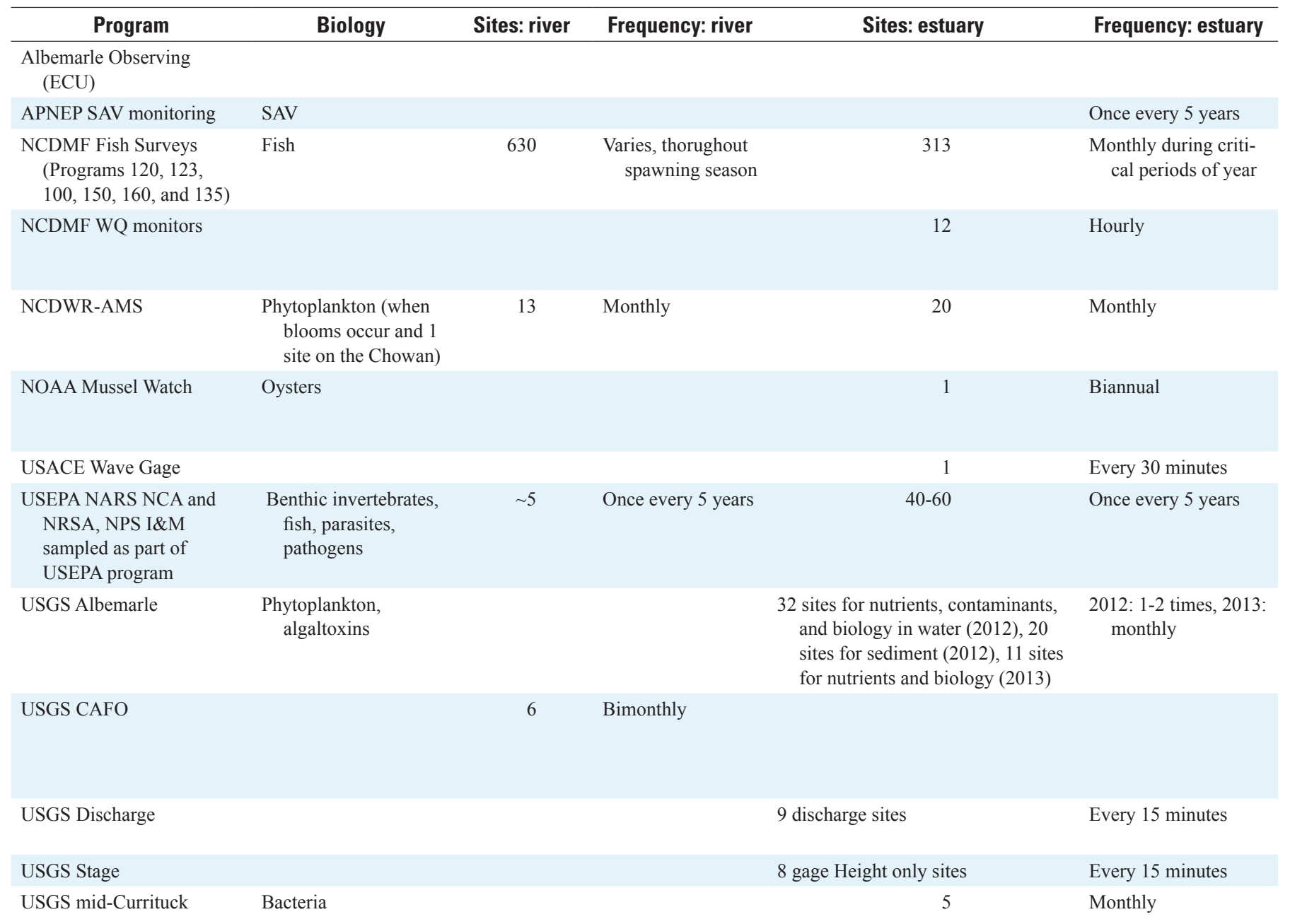

\begin{tabular}{|c|c|c|c|c|c|}
\hline USGS WQ monitor & & & & 4 & Every 15 minutes \\
\hline VADEQ Probablistic & $\begin{array}{l}\text { Bacteria, sediment } \\
\text { benthos }\end{array}$ & $\begin{array}{l}\text { Sites chosen at } \\
\text { random each } \\
\text { year }\end{array}$ & Once every year & Sites chosen at random each year & Once every year \\
\hline VADEQ Trend & & 30 & Bimonthly & 6 & Bimonthly \\
\hline VADEQ Fish Tissue & & 1 & Yearly & & \\
\hline $\begin{array}{l}\text { VADEQ Watershed Station } \\
\text { Network }\end{array}$ & Bacteria & $\begin{array}{l}\text { Sites chosen at } \\
\text { random each } \\
\text { year }\end{array}$ & Bimonthly & Sites chosen at random each year & Bimonthly \\
\hline
\end{tabular}

\footnotetext{
${ }^{1}$ Most programs take discrete physical measurements ( $\mathrm{pH}$, Temp, DO, Specific Conductance) as part of their routine monitoring program. Only continuously monitored parameters are noted here.
} 


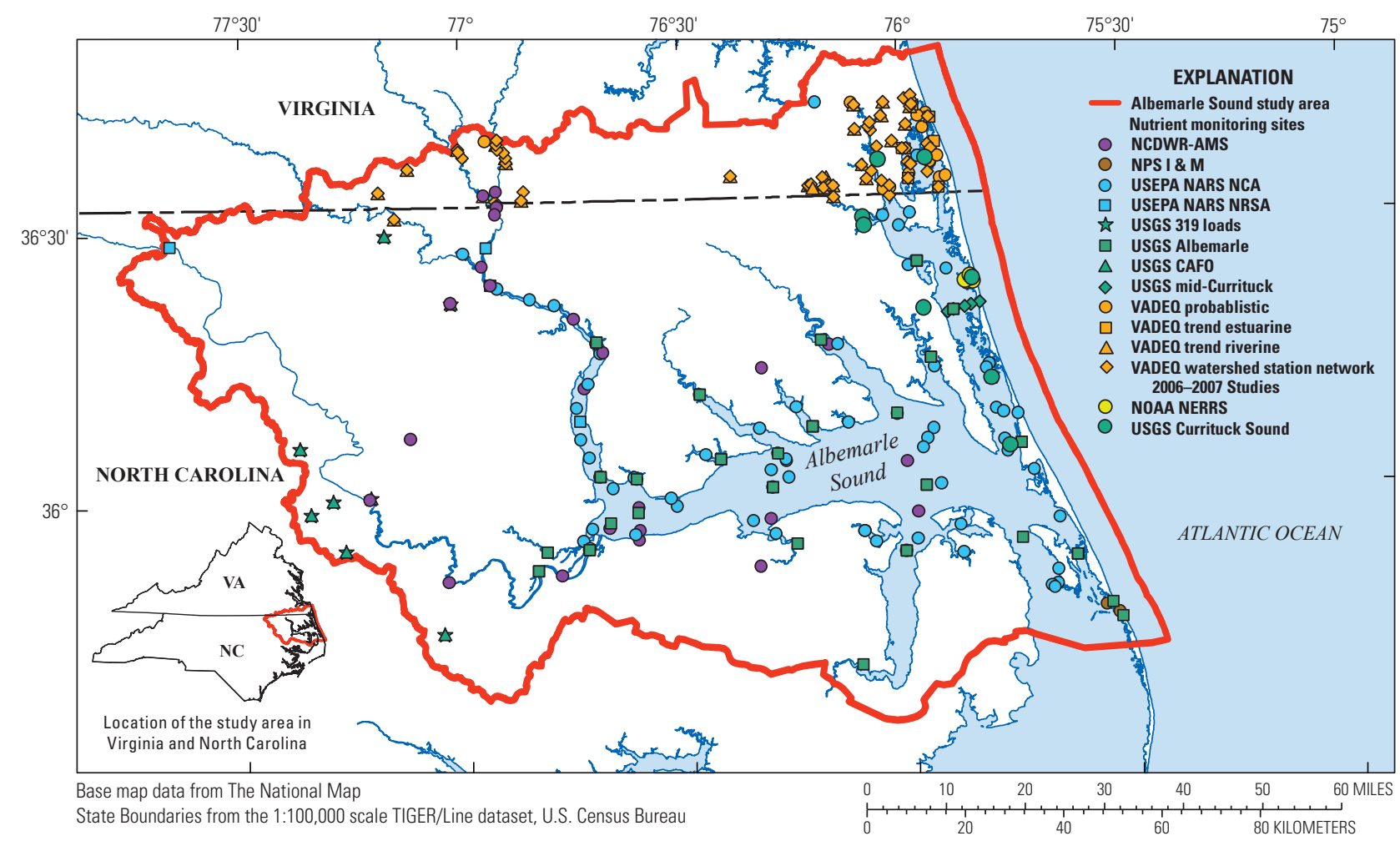

Figure 3. Nutrient monitoring in the Albemarle Sound estuary and rivers. [AMS, Ambient Monitoring System; CAFO, confined animal feeding operation; NARS National Aquatic Resource Surveys; NCA, National Coastal Assessment; NERRS, National Estuarine Research Reserve System; NCDWR, North Carolina Division of Water Resources; NOAA, National Oceanic and Atmospheric Administration; NRSA, National Rivers and Streams Assessments; USEPA, U.S. Environmental Protection Agency; USGS, U.S. Geological Survey; VADEQ, Virginia Department of Environmental Quality]

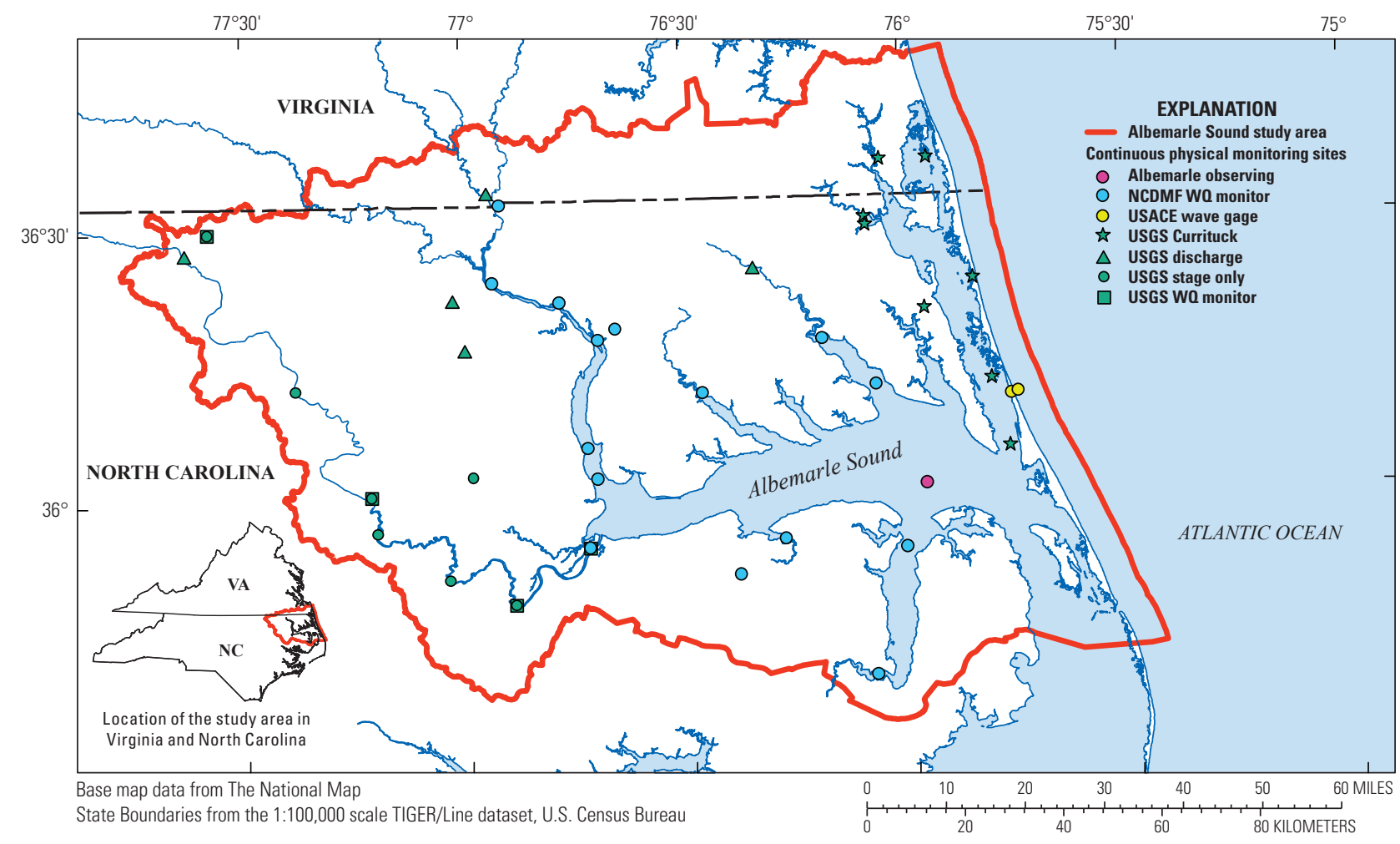

Figure 4. Continuous physical monitoring programs in the Albemarle Sound estuary and rivers. [NCDMF, North Carolina Division of Marine Fisheries; USACE, U.S. Army Corps of Engineers; USGS, U.S. Geological Survey; W0, water quality] 


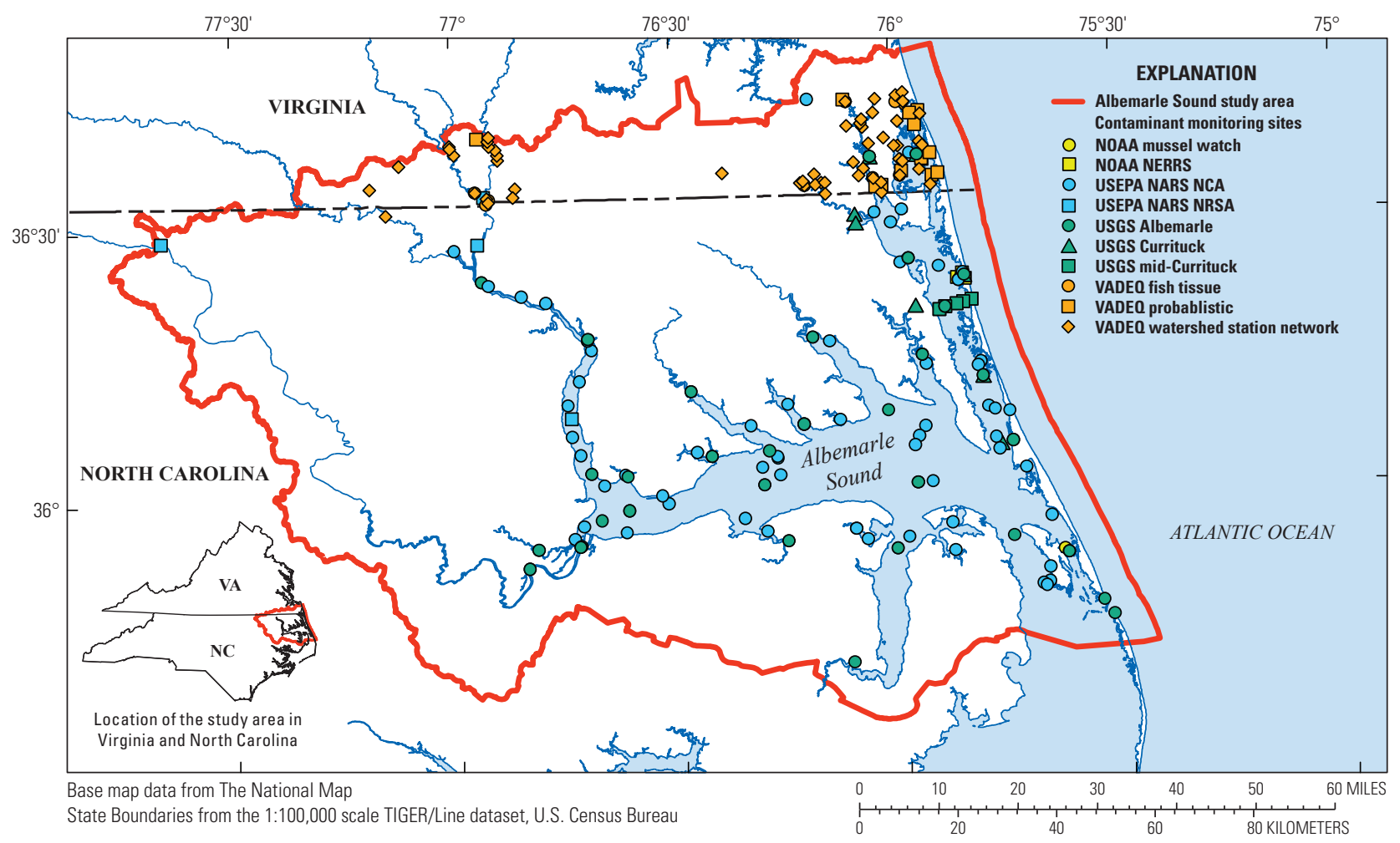

Figure 5. Contaminant monitoring in the Albemarle Sound estuary and rivers. [NARS National Aquatic Resource Surveys; NCA, National Coastal Assessment; NERRS, National Estuarine Research Reserve System; NCDWR, NOAA, National Oceanic and Atmospheric Administration; NRSA, National Rivers and Streams Assessments; USEPA, U.S. Environmental Protection Agency; USGS, U.S. Geological Survey; VADEQ, Virginia Department of Environmental Quality]

\section{Current Monitoring and Research}

$A P N E P$ - APNEP has led a multi-agency project designed to monitor the distribution of SAV (APNEP SAV monitoring) in the Albemarle-Pamlico Sound once every 5 years, starting in 2007. The extent of SAV beds visible from aerial platforms in coastal waters from Back Bay, Virginia to the North CarolinaSouth Carolina border are mapped through ground-truthed aerial surveys. The GIS coverages can be downloaded from the APNEP Web site at http://portal.ncdenr.org/web/apnep/maps.

$N C D M F$ - NCDMF fish surveys monitor important fisheries in the Albemarle Sound through several programs. The NCDMF Program 120 Estuarine Trawl Survey began in the 1970s with the goal of identifying primary nursery areas and other critical habitats, providing a long-term database of annual juvenile recruitment for economically important species and providing data that could allow for the evaluation of long-term environmental impacts of development projects. In 1989, protocols for the program were standardized and 105 core stations were selected. The NCDMF Program 123 Red Drum Juvenile survey is used to identify and characterizes red drum (Sciaenops ocellatus Linnaeus) nursery areas and to assist with the development of a juvenile abundance index for red drum. The NCDMF Program 100 Juvenile Anadromous Fishery Trawl/Seine survey was initiated in 1971 to determine the relative abundance, growth, and distribution of juvenile alosines (Alosa spp. H. F. Linck) and striped bass (Morone saxatilis Walbaum) and primary nursery areas and other critical habitats for the species. The NCDMF Program 150 Adult Anadromous Spawning Survey, begun in 1973, is used to monitor running ripe female herring and shad in the tributaries of the Albemarle Sound. The NCDMF Program 160 Anadromous Egg and Larval Survey was initiated in 1971 to verify the presence of alosine larvae and eggs following the capture of running ripe females. The NCDMF Program 135 Striped Bass Gill Net Survey, begun in 1990, is used to characterize the resident striped bass populations in the Albemarle Sound and Chowan River by size, age, sex, and relative abundance. Normally, physical parameters such as dissolved oxygen (DO), temperature, salinity, specific conductance, $\mathrm{pH}$ and secchi depth are recorded at each site as part of these fishery surveys. Thus, the NCDMF has an extensive database of discrete data documenting physical characteristics of the Albemarle Sound. In addition, NCDMF began Program P909 Albemarle Sound Water Quality Monitoring (NCDMF WQ monitors) in 2008 to collect continuous water-quality data at 12 stations in the Albemarle Sound area and to evaluate the effects of various water-quality parameters on river herring. The NCDMF maintains all data in their databases; the information can be obtained by contacting NCDMF staff at http://portal.ncdenr.org/web/mf/contact-dmf. 


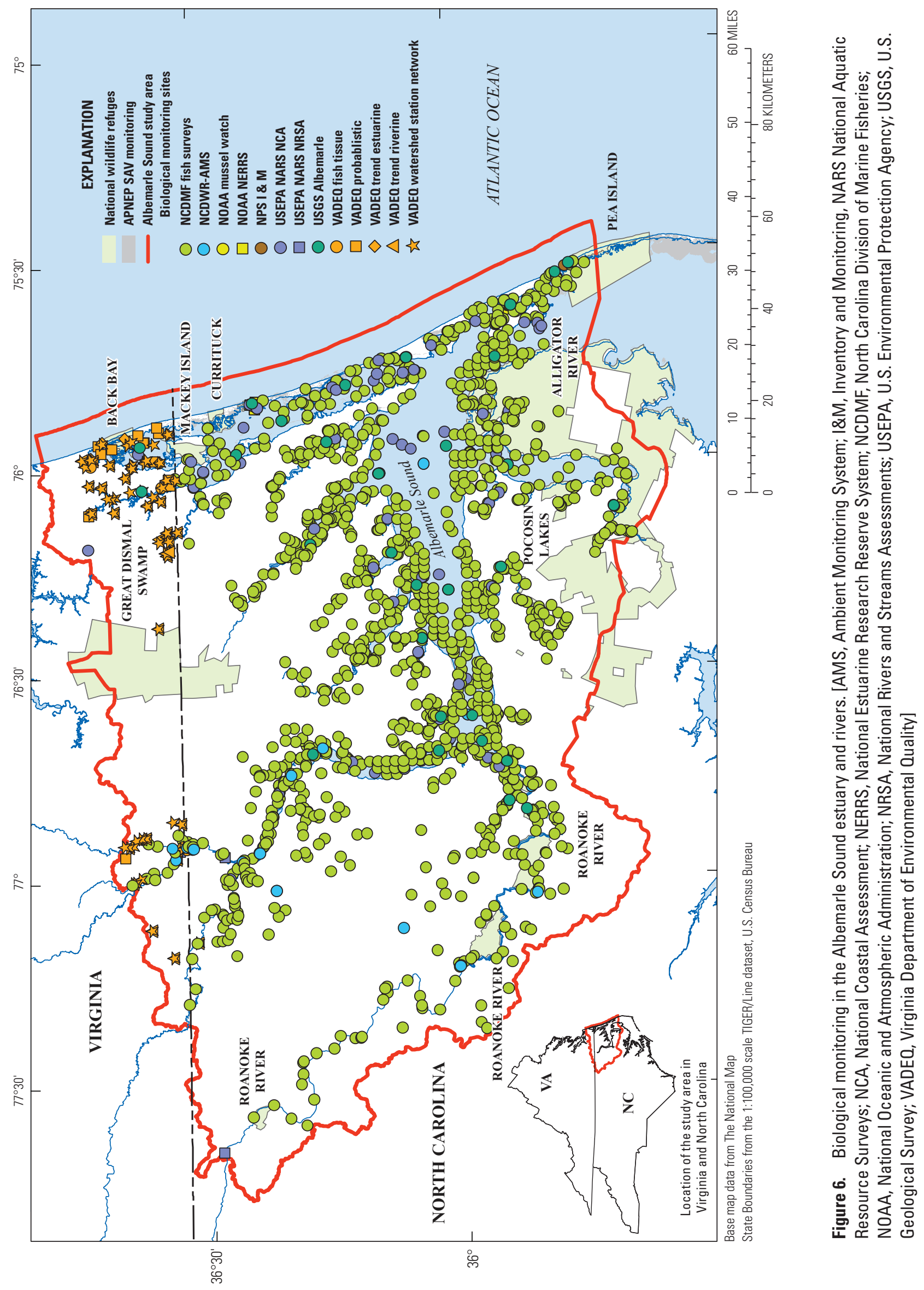


NCDWR - The NCDWR Ambient Monitoring System Program (NCDWR-AMS) has monitored 13 sites in the lower riverine sections of the Chowan and Roanoke Rivers and at 20 sites in the Albemarle Sound estuary embayment since 1970. Integrated water samples are collected monthly at a depth of twice the secchi-disk depth and analyzed for nutrients, total suspended solids, hardness, and chlorophyll $a$. Data are currently stored in the STORET (STOrage and RETrieval) data warehouse http://www.epa.gov/storet/.

NOAA-The NOAA Mussel Watch Program (NOAA

Mussel Watch) provides time-series data covering a broad suite of chemical contaminants in bivalves nationwide in order to support management decisions. The program has been active since 1986. One site in the Albemarle Sound is sampled on a biannual basis for various contaminants in oyster tissues and sediment. Data can be downloaded from the national status and trends data portal at http://ccma.nos.noaa.gov/about/coast/nsandt/download.aspx.

The U.S. Army Corps of Engineers (USACE) operates a field research facility (USACE wave gage) in Duck, North Carolina (N.C.). Instruments at the facility monitor changing waves, winds, tides, and currents in the estuary and nearshore environment. One site on the estuarine side of the barrier island has measured the water level in the sound at Duck since 1988. Data are available in real-time at $h t t p: / / w w w . f r f . u s a c e$. army.mil/.

EPA-The USEPA National Aquatic Resource Surveys (NARS) program was implemented in 2005 to survey aquatic resources in the Nation's rivers as part of the National Aquatic Resource Surveys (USEPA NARS NRSA) and estuaries as part of the National Coastal Assessment (USEPA NARS NCA). The program is probability-based, uses standardized field and lab methods, and is designed to yield unbiased estimates of the condition of the entire water resource being studied. Approximately five sites are sampled in riverine systems and 40 to 60 sites are sampled in estuarine systems for nutrients, contaminants, benthic communities, fish, parasites, and pathogens in the Albemarle Sound study region once every 5 years.

$N P S$ - The NPS Inventory and Monitoring (NPS I\&M) Program for water quality is based on EPA NARS protocols and includes data collection at NPS sites concurrently with the EPA NARS Program. Data are currently stored for both programs in the STORET data warehouse at $h t t p: / / w w w . e p a$. gov/storet/.

USGS-The USGS has been involved in monitoring rivers and estuarine embayments in the Albemarle Sound study region for decades. Data collected include continuous, real-time water-level, streamflow, and water-quality data, and discrete samples collected for specific studies. Most of these data are available online from the USGS National Water Information System database (NWIS Web) at http://waterdata.usgs.gov/nwis/nwis.

The USGS continuous real-time monitoring network is used to collect water quality (USGS WQ monitor), streamflow (USGS discharge), and gage height (USGS stage only) data. Data for North Carolina and Virginia typically are recorded at 15-60 minute intervals, stored onsite, and then transmitted to USGS offices every 1 to 4 hours, depending on the data-relay technique used. Data from real-time sites are relayed to USGS offices via satellite, telephone, and (or) radio and are available for viewing within minutes of arrival. Ongoing real-time monitoring efforts are established in the Albemarle Sound and the Roanoke, Chowan and Pasquotank River Basins. The most comprehensive effort incorporates a system of continuous water-quality sensors operating along the Roanoke River and funded through cooperative agreements between the USGS and eight partnering agencies.

Discrete data collected as part of investigative studies are also available from NWIS Web and WQX and summarized and published in USGS reports. Currently, the USGS has three active surface water studies in the Albemarle Sound study region. Beginning in August 2011, the USGS began the mid-Currituck Sound study (USGS mid-Currituck) with the objectives of establishing baseline bed-sediment chemistry and water-quality conditions of Currituck Sound in the vicinity of the planned construction of the mid-Currituck bridge. Baseline data will be used to evaluate the impacts associated with the bridge construction and bridge deck stormwater runoff in the second phase of the study. In 2011, the USGS began a study examining water-quality conditions in streams with agricultural land uses with a specific focus on nutrient loadings from confined animal feeding operations (USGS CAFO). The USGS recently analyzed long-term trends in nutrient data from monitoring stations where flow data were available and related estimated loads to watershed characteristics (USGS 319 loads). In 2012, the USGS began a monitoring program as part of the Albemarle Demonstration Project for the NMN (USGS Albemarle). The purpose of this project is to help fill current monitoring gaps identified in this report with additional monitoring of Albemarle Sound. The project has monitored nutrients, phytoplankton and algal toxins, and contaminants in sediment and in the water column at various unmonitored embayments located in the region including the Currituck Sound. Many of the sites overlap with a 2006-07 USGS Currituck water-quality study documenting baseline conditions in the sound.

VADEQ - The Virginia Department of Environmental Quality has two nutrient monitoring programs and one biological program in the Albemarle Sound. The Trend Monitoring Program is a long-term program with 30 stream/riverine sites (VADEQ trend riverine) and 6 estuarine sites (VADEQ trend estuarine). As part of the program, water samples are collected bimonthly for total nitrogen, total phosphorous, TSS, and chlorophyll $a$. The VADEQ Probabilistic Monitoring Program (VADEQ probabilistic) operates throughout Virginia. Each year, randomly selected sites are sampled for dissolved and particulate nutrients and light attenuation is measured. The number of sites sampled and their individual locations were not compiled for this program because the sampling sites change each year. Additionally, VADEQ also uses a probabilistic design to sample for contaminants each year 
(VADEQ Watershed Station Network). VADEQ Fish Tissue Surveys (VADEQ fish tissue) are conducted to assess the human health risks for individuals who may consume fish from State waters and to identify impaired aquatic ecosystems. Data for all programs are currently stored in the VADEQ's Comprehensive Environmental Data System Water Quality Monitoring (CEDS WQM) database, but there are plans to migrate the data to STORET. Data can be accessed by contacting VADEQ at $h t t p: / / w w w . d e q . v i r g i n i a . g o v / A b o u t U s / C o n t a c t s . a s p x$.

Numerous colleges and universities have current and historical research programs in the Albemarle Sound study region. Much of this information can be obtained from both the academic literature or student dissertations and theses. Some of the key universities working in the region include East Carolina University (ECU), University of North Carolina at Chapel Hill Institute of Marine Science (IMS), North Carolina State University, Elizabeth City State University, and Old Dominion University. ECU operates a continuous monitoring platform in the middle of the Albemarle Sound (Albemarle observing) and plans to add two more platforms to this network in 2014. Many of these North Carolina universities have satellite labs based out of the Coastal Studies Institute in Manteo, N.C. Examples of current research programs investigating the ecology of the Albemarle Sound study area include a zooplankton study that was initiated by UNC-IMS in 2006-7 and is now being continued by ECU in the Roanoke and Chowan Rivers and Albemarle Sound; anadromous fish surveys of the Roanoke River; SAV monitoring using acoustic Doppler techniques (ECU); creation of a coastal map atlas (ECU); and a study of morphological differences in banded killifish (Fundulus diaphanus Lesueur) living in rivers, streams and bays in eastern North Carolina. Data are normally maintained by the project investigator.

\section{Historical Monitoring and Research}

Many studies have been conducted in the Albemarle Sound during the past century. A complete bibliography of all work prior to 1988 is available in Bales and Nelson (1988). In addition, several comprehensive monitoring and research efforts were undertaken during the 1980s and 90s as part of the Albemarle-Pamlico Estuary Study, on APNEP's Web site (http://www.apnep.org/web/apnep/reports), or the National Water Quality Assessment Program (Harned and Davenport, 1990). Important, recent monitoring efforts in the region have been conducted by the following State and Federal agencies:

$N C D C M$ - The NCDCM collects and analyzes data for erosion rates, wetlands conservation, and restoration to assess the impacts of coastal development. In 2012, the NCDCM, in partnership with East Carolina University, mapped the estuarine coastline of North Carolina. The maps identify shoreline types (that is, swamp forest, marsh, sediment bank, or manufactured) and document the length of hardened structures along the coast. The GIS coverages can be downloaded from the NCDCM Web site at http://portal.ncdenr.org/web/cm/download-spatial-datamaps-oceanfront.
NOAA-The NOAA National Estuarine Research Reserve System (NOAA NERRS) conducted baseline assessments of their national reserve system in 2004. The water column was sampled for nutrients and chlorophyll $a$; sediment was sampled for contaminants including pesticides, metals, trace metals, polychlorinated biphenyls, and polycyclic aromatic hydrocarbons; and fish and benthic communities were assessed on the reserves. More information is available at http://www.chbr.noaa.gov/par/coastal_ecology.aspx.

USFWS - The USFWS has studied the surface water and biology of the estuary embayment and riverine systems of the Albemarle Sound. These studies include an assessment of contaminants in biota and sediment of the region, with an emphasis on river mouths near wildlife refuges, studies of mercury in fish and osprey tissue, studies of dioxin in wood ducks and osprey, and assessments of toxicity and aquatic community impacts associated with wastewater-treatmentfacility effluent. Historically, data have been stored in individual refuges or USFWS Ecological Services branch offices, but the USFWS is compiling this information into a national Priority Refuge Inventory and Monitoring Report database (PRIMR). More information about this process is provided in the wetlands inventory section herein.

USGS-In 2006-7, the USGS led a multi-agency data collection effort in the Currituck Sound (USGS Currituck). The purpose of the study was to document water-quality trends in the sound and collect the data needed to develop a coupled hydrodynamic and water-quality model. Continuous water-quality monitoring devices were deployed at eight sites to measure dissolved oxygen, $\mathrm{pH}$, temperature, specific conductivity, and water level every 15 minutes. Nutrient samples were collected at the sites on a monthly basis. Data from the study are available at http://nc.water.usgs.gov/projects/currituck/data.html.

\section{Monitoring Gaps Identified for Estuary Embayments and Riverine Monitoring}

Monitoring gaps for individual parameter groups are discussed in the following sections, including comparisons of the current monitoring networks to the recommended design of the NMN and suggested improvements to meet the NMN design requirements.

\section{Nutrients}

Currently, nutrients are routinely measured in the Albemarle Sound estuary and rivers as part of State and Federal programs (fig. 3). The monitoring programs meet NMN design requirements for nutrient transport in estuary embayments because 20 sites are monitored monthly by the State of North Carolina along the salinity gradient. Current monitoring programs do not meet the estuarine condition requirement that specifies 50 sites should be monitored on a monthly basis for 12 months once every 5 years. As part of the Albemarle demonstration project, nutrients will be monitored 
at 7 additional sites in currently unmonitored embayments of the Albemarle Sound Estuary. Samples were collected by the USGS monthly from March 2013 through February 2014. The two major tributaries flowing into the Albemarle Sound are the Chowan and Roanoke Rivers. Currently, NCDWR monitors nutrients monthly in the Roanoke River. There may be a need to target high-flow samples as specified by the NMN design. Both VADEQ and NCDWR monitor the Chowan River for nutrients. There is currently no streamflow gage on the Chowan River, but several gages exist on the tributaries feeding into it. Discharge sites and nutrient monitoring sites overlap at 4 of the 5 discharge stations located on these tributaries. The three sites in Virginia that represent the majority of the inflow to the Chowan River are monitored bimonthly by the VADEQ for total phosphorus and total nitrogen. Thus, there is a need to increase the frequency of nutrient samples collected and the types of analytes sampled in Virginia. In addition, there may be a need to add riverine nutrient sites to selected tidal creeks flowing into the major embayments of the Albemarle Sound, including Currituck Sound.

\section{Physical Parameters}

Almost all programs in the estuaries and rivers routinely measure physical parameters such as $\mathrm{DO}, \mathrm{pH}$, temperature, specific conductance, and salinity, and secchi-disk depth when visiting a site to monitor for nutrients, contaminants, or biological parameters. Thus, the network design requirement for transport is currently met in both the riverine and estuarine systems. Any improvements to the nutrient monitoring network would improve the physical monitoring network. Discrete physical monitoring could be improved by developing methods for entering all discrete measurements into a single database such as the USEPA Water Quality Exchange (WQX) network. Thus, only short-term variability is considered to be a monitoring gap and only continuous monitoring programs are discussed further (fig. 4).

The major tributaries (Roanoke River and Chowan River) flowing to the Albemarle Sound are currently gaged to measure continuous discharge upstream from any tidal influences. On the Roanoke River, the sole streamflow gage is located downstream of the Roanoke Rapids dam. This gage is supplemented by seven stage-only sites downstream along the Roanoke River from the Roanoke Rapids dam to Albemarle Sound. Four of these sites have continuous water-quality monitors operated by the USGS. Flow on the Chowan River is influenced by estuarine processes from the confluence of the Blackwater and Nottaway Rivers to the mouth of the Chowan River. Discharge on the Chowan River is gaged at five tributaries that represent approximately 63 percent of the drainage area of the Chowan River and the major freshwater influences. Stage-only gages are needed on the Chowan River to improve understanding of freshwater inputs from the Chowan River to the Albemarle Sound and tidal influences on the Chowan River. NCDMF operates several continuous water-quality monitors on the Chowan River. The data are available from NCDMF in Microsoft Excel format, but data quality and delivery could be improved if data became publically available through a real-time system such as NWIS Web. Current monitoring on the Roanoke and Chowan River satisfies the network design for continuous physical monitoring but could be improved by monitoring the tidally influenced portions of the Chowan River and making a subset of NCDMF's water-quality monitors that measure dissolved oxygen, $\mathrm{pH}$, temperature, and specific conductance/salinity on the Chowan available in real-time.

The Pasquotank River is the only other tidal creek flowing into an embayment of the Albemarle Sound that is monitored for discharge. Two sites on Currituck Sound are currently monitored for stage only by either the USGS or the USACE. Several continuous (hourly) water-quality monitors are operated by NCDMF in other estuarine embayments and should be upgraded so that they can deliver information in near real time. Because of the large number of embayments and the complexity of the system, the continuous monitoring network should be expanded and a site should be added on the western end of the sound. East Carolina University will work with the USACE in 2014 to deploy three continuous monitors that will measure wave height, stage, and water quality near Roanoke Island, N.C.; Duck, N.C.; and in the Albemarle Sound near the mouth of Alligator River, which will help complete the NMN network design for the eastern part of the Albemarle sound.

\section{Contaminants}

Sediment contaminant monitoring currently meets the network design because of the USEPA NARS program that monitors 40 to 60 sites for contaminants in sediments and fish in the Albemarle Sound once every 5 years. VADEQ monitors sediment contaminants every year as part of their probabilistic monitoring network. The NOAA Mussel Watch program monitors over 100 contaminants in bivalves and sediments at one site in the Albemarle Sound on a biannual basis.

Currently, there is no ongoing monitoring of contaminants in surface waters of the rivers or estuaries in North Carolina. The NCDWQ previously collected metals data as part of their water-quality sampling program but does not do so currently. Instead, water-quality monitoring programs for contaminants in North Carolina are limited in scope. For example, the USGS mid-Currituck bridge (USGS mid-Currituck) study is currently monitoring water for several contaminants at five sites along the proposed mid-Currituck bridge transect. The USFWS, USGS, and several universities have completed contaminant studies related to water quality in the Albemarle region. As part of the Albemarle Sound demonstration project, metals were monitored in water at 33 sites and sediment at 20 sites in 2012 to help meet this gap. Water samples were screened for two common-use pesticides at 33 sites in 2012 and 11 sites in the spring, summer, and fall of 2013 (fig. 5).

\section{Biology}

Several agencies are currently monitoring the estuaries and rivers for fish, macroinvertebrates, phytoplankton and 
habitat of the Albemarle Sound (fig. 6). The NCDMF routinely monitors the estuary and its tributaries for fish communities, and long-term datasets on fish community structure are available. EPA NARS monitors benthic communities once every 5 years. APNEP is surveying the extent of SAV in the region once every 5 years. In addition, APNEP is supporting the development of an SAV sentinel site network of field stations in 2014, with the intention of monitoring not only SAV extent but species composition as well; monitoring would be on an annual or more frequent basis. The NCDCM has recently completed a survey of the extent and type of estuarine shoreline in North Carolina. The USFWS and NPS conduct refuge or park-specific monitoring programs for birds, sea turtles, and vegetation. Phytoplankton are periodically monitored at one site each on the Pasquotank and Chowan Rivers during the growing season by the NCDWR, and additional samples are collected by field crews when algal blooms are observed during water-quality sampling. Monitoring of phytoplankton, zooplankton, and benthic invertebrates in the Albemarle Sound is needed because these groups represent the base of the food chain and harmful algal blooms can have negative impacts on water quality and biology. In 2012, as part of the NMN demonstration project, the USGS Albemarle pilot program sampled phytoplankton in partnership with NCDWR at 32 sites in the Albemarle Sound. Phytoplankton samples were analyzed by NCDWR for counts and taxonomic identification, and by the USGS for algal toxins. Spring, summer, and fall samples were collected at 11 sites in the Albemarle Sound during 2013.

\section{Groundwater}

The USGS and NCDWR are the two organizations with major groundwater-monitoring efforts in the region. The USFWS is conducting groundwater monitoring as part of their peatland restoration project in the northeastern part of the region.

NCDWR - The NCDWR has been monitoring groundwater levels and quality at their network of wells since 1977, as mandated by the Federal Clean Water Act (fig. 7). Currently, this program includes continuous measurements of groundwater levels at 81 sites (NCDWR continuous water level), quarterly measurements of groundwater levels at 104 sites (NCDWR quarterly water level), and measurements of chloride concentration, specific conductance, $\mathrm{pH}$, and salinity at the monitoring wells once every 2 to 3 years (NCDWR chloride monitoring). Sites are often well clusters so that multiple aquifers can be sampled at a single location. NCDWR maintains all data

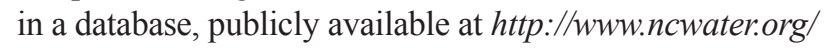
Data_and_Modeling/Ground_Water_Databases/.

$\overline{U S F} \bar{W}$ - The USFWS has been leading an effort on the Great Dismal Swamp National Wildlife Refuge (NWR) to better understand the hydrology of peatlands that have been historically ditched and drained within the Coastal Plain (USFWS GDS; fig. 7). The study objectives are to identify (1) the relationship of water levels in the ditches to groundwater levels adjacent to the ditches and in the interior habitats, (2) the current nutrient chemistry and possible transport pathways, and (3) the existing hydrologic conditions prior to installation of a large-scale water-control structure. The USGS, other State agencies including APNEP, and universities each have assisted with this effort. More information regarding the USFWS data management efforts is available by contacting the Great Dismal Swamp NWR at greatdismalswamp@fws.gov.

USGS - The USGS has been measuring water quality and water levels at a network of nine shallow agricultural wells in the region since 1994 as part of their National Water Quality Assessment program (USGS NAWQA; fig. 7). Water levels have been measured at all sites on an annual basis. A subset of seven wells has been sampled biennially for major ions, trace elements, metals, nutrients, volatile organic compounds, and pesticides. The other two sites have been sampled twice for water quality over the course of the program. This network of wells is scheduled to be resampled in 2014. In addition, a study of public water-supply wells in the region was initiated in 2013. There are currently two USGS research studies in progress in the region. The USGS has been monitoring 21 wells since 1997 to document changes in chloride, major ions, nutrients, water levels and groundwater flow that are potentially related to groundwater withdrawals and altered flow directions in confined Coastal Plain aquifers (USGS Chloride). The USGS has also been monitoring water levels and sampling for total solids, isotopes, major ions, and metals in 60 wells near Virginia Beach since 1999 as part of an effort to define the hydrogeologic framework of shallow aquifers in the region and document changes in water quality and water levels related to domestic withdrawals (USGS Virginia Beach). Most of these data are available online from NWIS Web at http://waterdata.usgs.gov/ nwis/nwis.

\section{Monitoring Gaps Identified for Groundwater}

The guidance for groundwater monitoring is still in development. Currently, the NMN only makes recommendations for nutrients and suggests that dissolved nitrate plus nitrite be sampled as a Tier 1 analyte, dissolved ammonium and dissolved orthophosphate be sampled as a Tier 2 analyte and dissolved organic carbon be sampled as an ancillary analyte. One way to improve current groundwater monitoring efforts with minimal additional effort and cost would be for the NCDWR to sample nutrients once every 2 to 3 years at the same time as their chloride sampling at wells in the shallow-aquifer systems because nutrient contributions from groundwater can be significant in estuaries (Burnett and others, 2006).

\section{Atmospheric Deposition}

$N A D P$ - The National Atmospheric Deposition Program (NADP) is a nationwide network of precipitation monitoring sites. The NADP network represents a cooperative effort between many different groups, including the State 


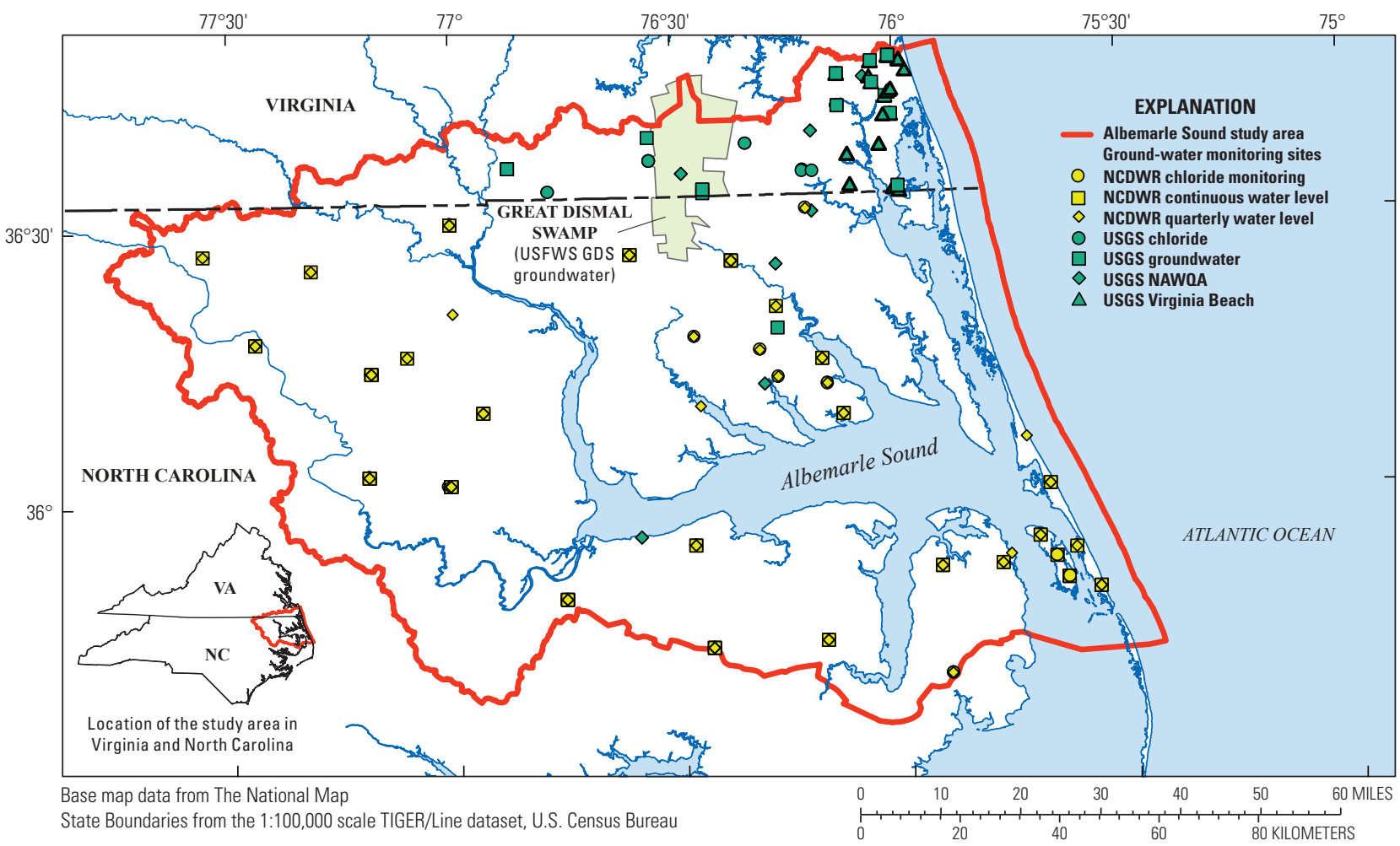

Figure 7. Groundwater monitoring sites in the Albemarle Sound region. [NAWQA, National Water Quality Assessment (Program); NCDWR, North Carolina Division of Water Resources; USGS, U.S. Geological Survey]

Agricultural Experiment Stations, the USGS, USDA, and many other governmental and private entities. Six active NADP stations are located within or adjacent to the Albemarle region (fig. 8). All stations have measured acids, nutrients, and base cations on a weekly basis since 1978 (National Trends Network, NADP NTN). In addition, two sites have measured total mercury in precipitation on a weekly basis since 1996 (Mercury Deposition Network, NADP MDN) and one site (Ammonia Monitoring Network, NADP AMoN) has measured dry, depositional ammonia concentrations since 2010. Data are stored in a database and available online at http://nadp.sws. uiuc.edu/data/.

North Carolina State Climate Office-The North Carolina State Climate Office coordinates the Climate Retrieval and Observations Network of the Southeast (CRONOS) program through the North Carolina Environmental and Climate Observing Network, which consists of more than 100 weather and environmental observing stations across the State. The goal is to have at least one automated weather station in each county. CRONOS sites provides wind, temperature, humidity, precipitation, and soil moisture data from stations operated by the State Climate Office, National Weather Service, Federal Aviation Administration, and the U.S. Natural Resource Conservation Service in North Carolina and the surrounding states. Currently there are 54 active stations in the CRONOS network located in the Albemarle region (fig. 8). Not all stations monitor all parameters and some of these stations overlap with the NOAA Citizen Climate Network. Data are available online at $\mathrm{http://www.nc-climate.ncsu.edu/cronos/index.php.}$

NOAA-NOAA has been operating a community collaborative rain, hail, and snow monitoring network (CoCoRaHS) since 1998. There are currently $78 \mathrm{CoCoRaHS}$ sites in the Albemarle study area (fig. 8). The goals of the network design are to (1) provide accurate and timely precipitation data, (2) increase the density of precipitation data available throughout the Nation by encouraging volunteer weather observation, (3) encourage citizens to participate in meteorological science and heighten awareness about weather, and (4) provide resources for teachers, educators, and the community. Data are available online at http://www.cocorahs.org/.

USFS - Since 2000, the USFS Southern Research Station has been operating a flux monitoring tower in a loblolly pine (Pinus taeda L.) plantation in the Coastal Plain (USFS flux tower). The station measures $\mathrm{CO}_{2}$ concentration and flux; soil heat flux; water vapor flux; sensible (conductive) heat flux; water vapor concentration; latent heat flux; incoming radiation, including photosynthetically active radiation; net ecosystem exchange of $\mathrm{CO}_{2}$; precipitation; barometric pressure; relative humidity; air and soil temperature; vapor pressure deficit; wind direction; and wind speed. The research and science objectives of the North Carolina Loblolly Pine site are to (1) examine interannual differences in precipitation as a driver of ecosystem processes; (2) characterize the carbon pools and fluxes of the lower Coastal Plain forest; (3) characterize the sources of interannual variability in the fluxes, 
including sensitivity to natural disturbances such as severe droughts; and (4) examine the effects of ecosystem conversion from wetlands to intensively-managed forests on plant hydraulic properties and water balances. Data are available online at http://ameriflux.ornl.gov/fullsiteinfo.php? sid $=71$.

\section{Monitoring Gaps Identified for Atmospheric Deposition}

Currently, the NADP network meets the NMN design requirements for atmospheric deposition. The one ammonia deposition site is located outside the network boundary. The design could be improved by adding an additional ammonia deposition site within the study area boundary.

\section{Wetlands}

Much of the native land cover in the Albemarle Sound study region consists of peat bogs known as pocosin wetlands. During the 20th Century, many of these wetlands were deforested, ditched, and drained for agriculture. As of 2006, 28.1 percent of the Albemarle Sound study region was classified as wetlands, although many of these wetland habitats have been affected by ditching and draining to allow for agriculture (Fry and others, 2011). Currently, there is interest in understanding the hydrology of the region and restoring wetlands that have been altered because of ditching and draining.

$E C U$ - Starting in 2006, ECU and Duke University researchers teamed up to study ecosystem services provided by wetlands at the Timberlake Restoration site (ECU Timberlake study; fig. 9). The study examined the biogeochemical consequences of wetland restoration and saltwater intrusion on nutrient cycling and greenhouse gas emissions in a former agricultural field.

USEPA - The USEPA is using advanced remote-sensing technologies for determining how wetland ecosystem services respond to increases or decreases in nutrient inputs from agroecosystems (USEPA wetland). Airborne imaging spectroscopy is used to measure plant chlorophyll absorption and relate it to biomass nitrogen content. As part of this project, the USEPA is sampling plant tissues at four wetland sites for major ions, trace elements, total phosphorous, and nitrogen three times per year to help verify their model (fig. 9).

The Nature Conservancy (TNC) - Since 2009, TNC has conducted a wide variety of hydrologic monitoring at the Alligator River NWR as part of the Albemarle-Pamlico Climate Change Adaptation Project (APCCAP). The goal of APCCAP is to develop, implement, and refine strategies for coastal wetland habitats and communities to handle climate

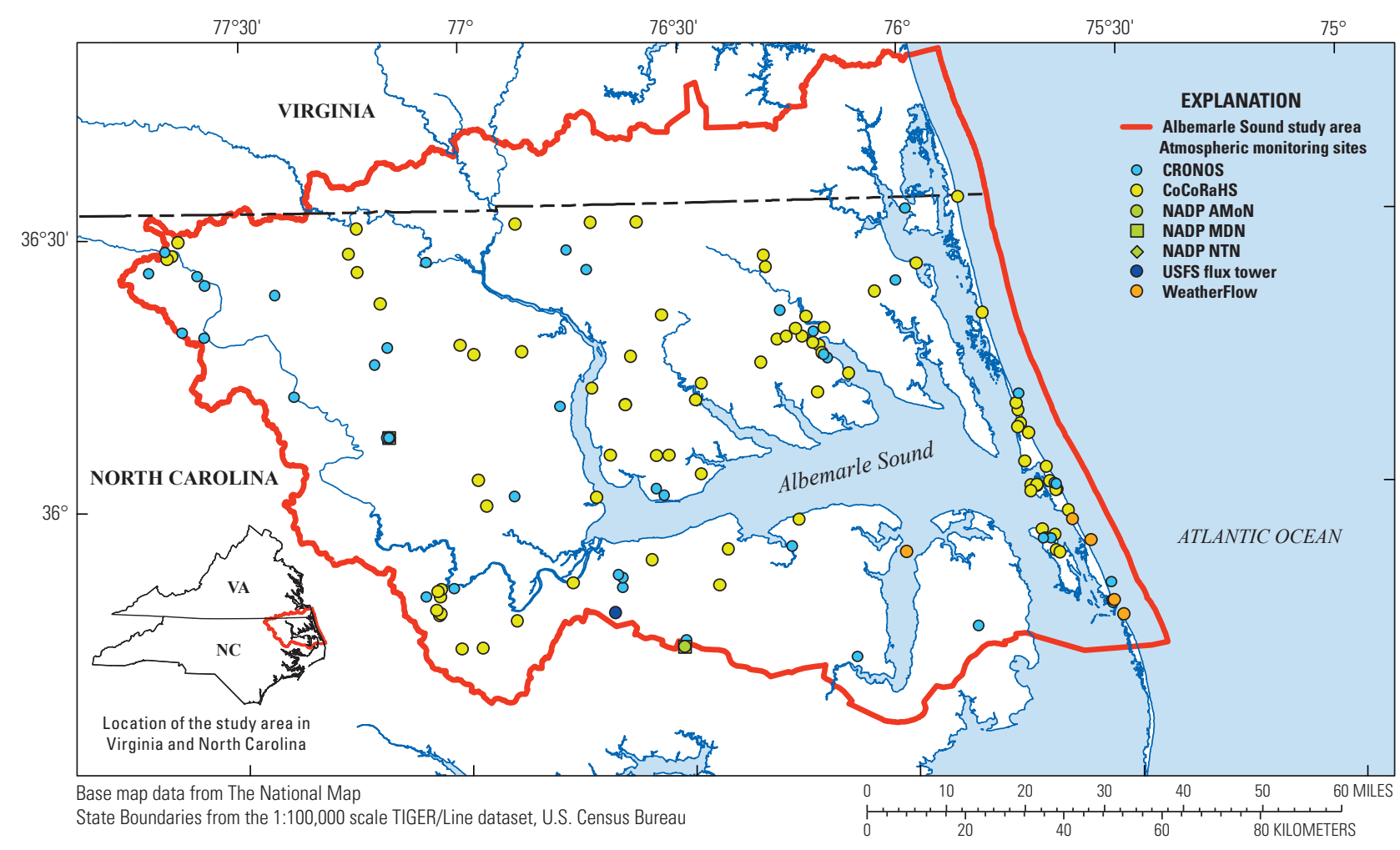

Figure 8. Atmospheric depositional monitoring in the Albemarle Sound region. [AMoN, Ammonia Monitoring Network (NADP); CRONOS, Climate Retrieval and Observations Network of the Southeast; CoCoRaHS, Community Collaborative Rain, Hail, and Snow Network; MDN, Mercury Deposition Network; NADP, National Atmospheric Deposition Program; NTN, National Trends Network (NADP); USFS, U.S. Forest Service] 


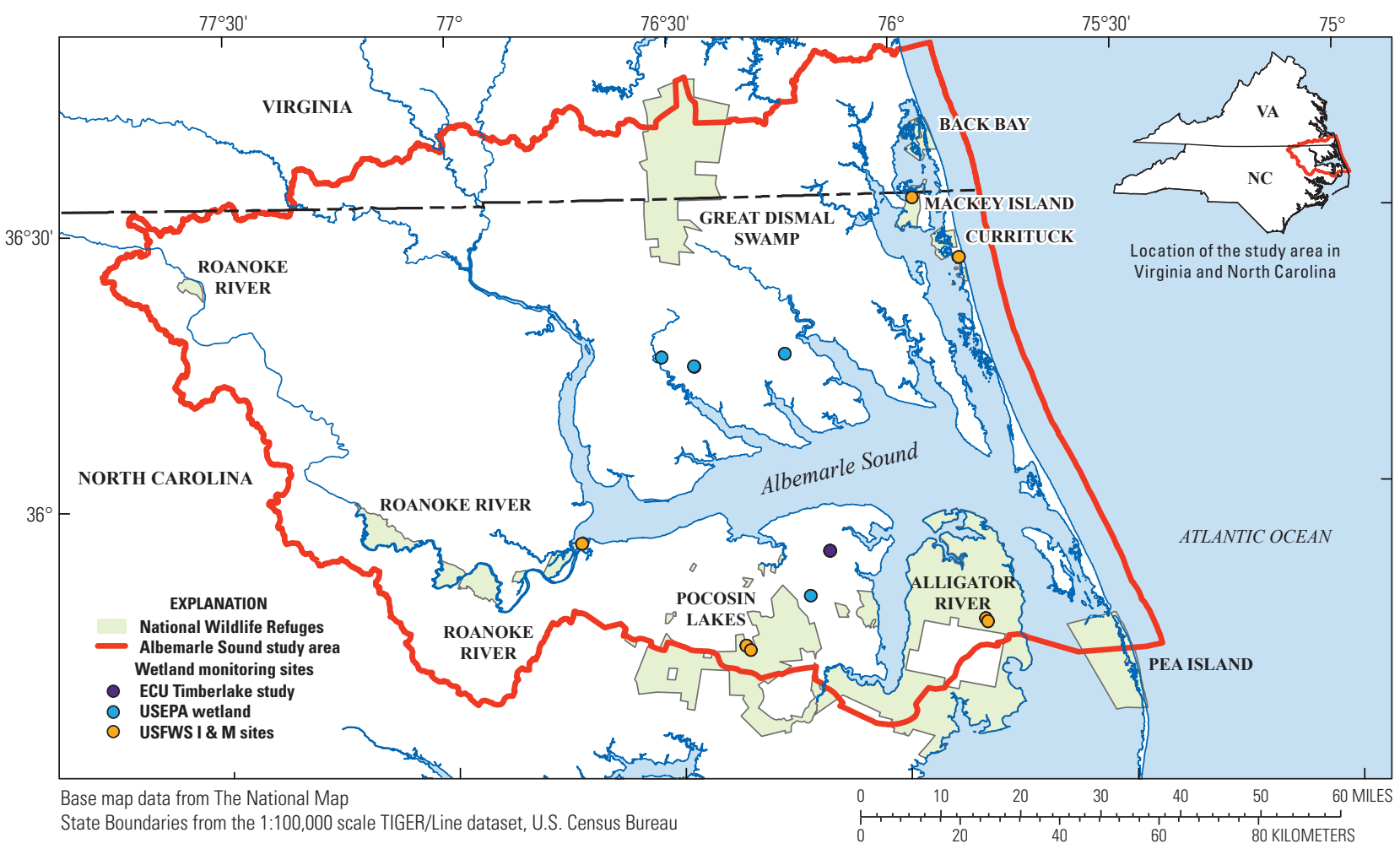

Figure 9. Wetland monitoring in the Albemarle Sound region. [ECU, East Carolina University; I\&M, Inventory and Monitoring; USEPA, U.S. Environmental Protection Agency; USFWS, U.S. Fish and Wildlife Service]

change impacts such as sea-level rise. Monitoring reflects the three components of the project: (1) hydrologic restoration through water control structures and effective ditch management; (2) oyster reef restoration to build coastal resilience and improve water quality; and (3) enhanced ecosystem transition through vegetative restoration efforts.

USFWS - The USFWS is an important land manager in the Albemarle Sound study region and currently manages 8 NWRs within the study area and 2 additional wildlife refuges adjacent to the Albemarle Sound study region (fig. 9). Many of these wildlife refuges have been designed to protect and conserve pocosin wetland habitats but have been altered because of the extensive ditching and draining that occurred during the past century. Much of the research and monitoring that has occurred at these individual refuges has focused on understanding how wetland hydrology has been altered and its impact on wetland communities. Currently, there are three major wetland restoration projects being implemented at Alligator River NWR, Great Dismal Swamp NWR, and Pocosin Lakes NWR. Wetland restoration projects normally consist of plugging refuge canals for the purpose of limiting saltwater intrusion into the wetlands, suppressing wildfires by restoring soil moisture, and restoring natural vegetative communities. Significant wetland monitoring programs have been implemented as part of these restoration projects, but are specific to the individual refuge where they are occurring.

USFWS has recently recognized the need to implement an inventory and monitoring (I\&M) program with standardized protocols and to create a database that allows entry and comparison of information across the refuge system (USFWS I\&M sites). Starting in 2010, the USFWS implemented a national I\&M program. The I\&M network is a coordinated program within the USFWS that was established to gather, analyze, and disseminate information about the status, trends, and management response of species and habitat within the refuge system. The I\&M program represents a shift to systematic data collection among refuges and includes implementing a central database where all data can be reposited and queried. In 2012, the USFWS began implementation of their Marsh Elevation Monitoring Network at 3 sites within or adjacent to the Albemarle Sound study region (fig. 9). The purpose of the Marsh Elevation I\&M program is to observe the impacts of sea-level rise and the changes in priority habitats as a result thereof, observe the rates of wetland elevation change and relative sea-level rise, and forecast the longevity of these habitats in refuges.

Prior to implementation of the I\&M program, individual refuges conducted ad hoc monitoring to better understand, manage, and protect refuge-specific habitats and biota (National Wildlife Refuges) (fig. 9). Examples of current and historical monitoring programs that have involved individual refuges in the Albemarle Sound study region include (1) monitoring waterfowl use; (2) monitoring the presence and effectiveness of treatment of invasive species, such as some reeds (Phragmites Adans. spp.), alligator weed (Alternanthera philoxeroides [Mart.] Griseb.), and river 
hemp (Sesbania Scop. spp.) in moist soil units; (3) monitoring Atlantic white cedar (Chamaecyparis thyoides [L.] Britton, Sterns \& Poggenb.) restoration activities, (4) monitoring amphibians, specifically to determine the extent of amphibian abnormality; and (5) monitoring of contaminants in biota and sediment. Previously, much of these data have been inconsistently collected across the refuge system and have been stored in either paper files or individual refuge databases. In the future, individual refuges can continue to augment I\&M programs with refuge-specific monitoring designed to meet management needs. Currently, the USFWS is undertaking the task of getting this information into a central database known as the Priority Refuge Inventory and Monitoring Report (PRIMR) database. After data compilation and quality checks are completed, the PRIMR database will support the production of summary reports of individual inventory \& monitoring projects on NWRs. The USFWS also is undertaking a major archiving application called ServCat (Service Catalog). ServCat will create records, complete with metadata from documents such as reports, surveys, databases, geospatial data, and images. ServCat information will be retrievable using text or geospatial search tools.

\section{Monitoring Gaps Identified for Wetlands}

Currently, there are no specific NMN criteria for wetland monitoring, but wetlands represent an important resource in the region. Current monitoring is limited to FWS refuges or localized studies by academic investigators and expansion of monitoring to a regional network is needed. The USFWS could assist APNEP with designing a wetland monitoring network for the region.

\section{Beaches}

The beaches of the barrier islands separate the Albemarle Sound from the Atlantic Ocean and provide important nesting habitat for many species, including endangered sea turtles and shorebirds. The beaches are also essential to the local economy, which depends on income from tourism each year. Thus, the health of the beaches must be monitored and maintained for both the species that depend on them and for the people who use them for recreation.

$N C D M F$ - Currently 52 beaches and 134 shellfish beds in the Albemarle Region are routinely monitored by the NCDMF Shellfish Sanitation Program (NCDENR Shellfish Sanitation) for total and fecal coliform bacteria and by the NCDMF Recreational Water Quality (NCDENR Recreational Water Quality) Program for enterococci bacteria (fig. 10). Sites include ocean beaches, estuarine swimming areas, and shellfish growing areas. The public is notified when bacteriological standards for safe bodily contact or shellfish consumption are exceeded. Recreational beach monitoring data are currently stored in the STORET database at http://www.epa.gov/storet/. Shellfish sanitation data are stored in an Access database maintained by NCDMF.

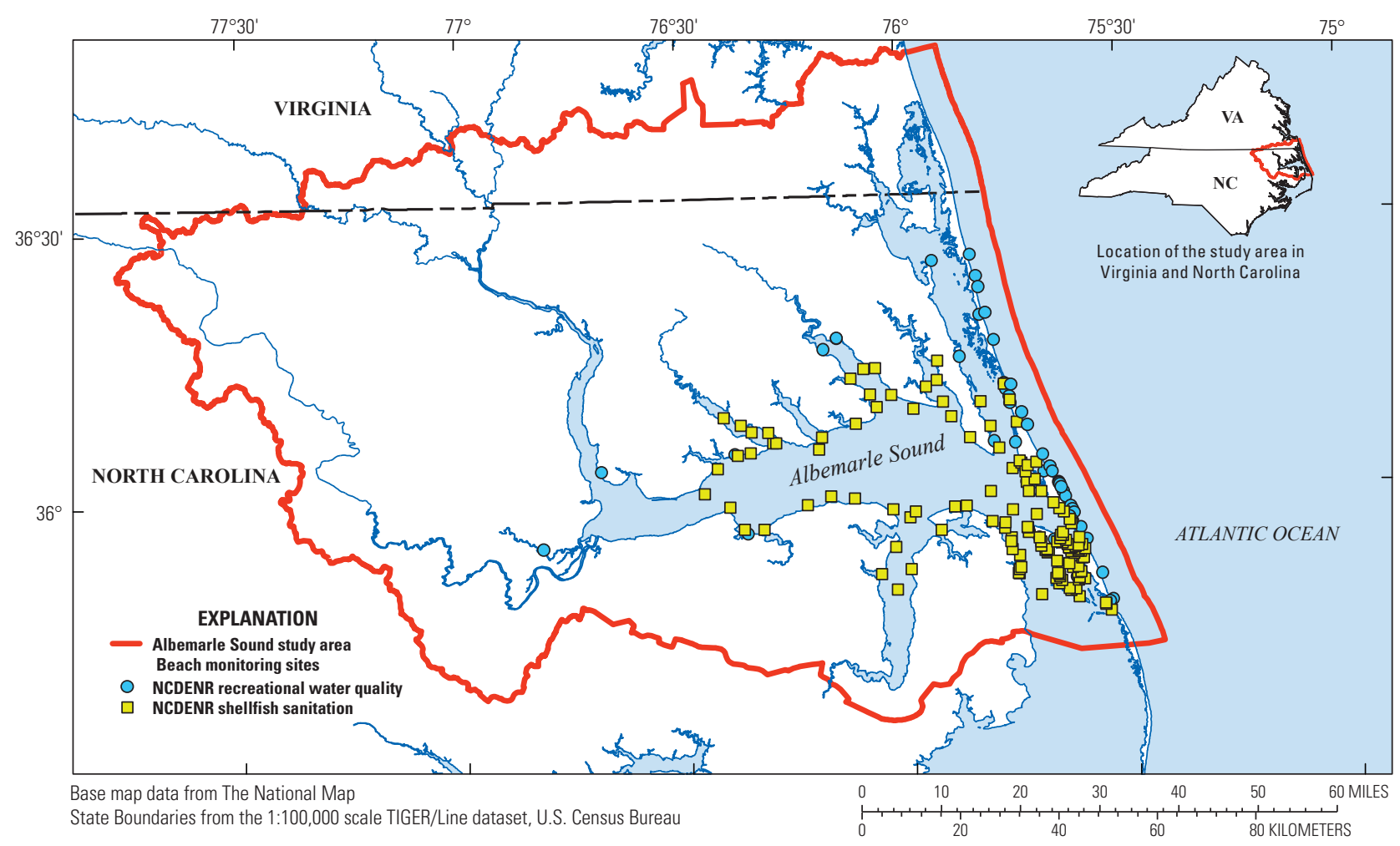

Figure 10. Beach monitoring in the Albemarle Sound region. [NCDENR, North Carolina Department of Environment and Natural Resources] 
NPS and USFWS - The NPS and USFWS monitor birds, sea turtles, and other flora and fauna at national parks and national wildlife refuges located on the barrier islands. USFWS monitoring data for wildlife refuges will be available through the PRIMR database (as discussed in the Inventory of Wetlands section) or one can contact individual parks and wildlife refuges to learn more about their beach monitoring programs.

USACE - The USACE field research facility at Duck, N.C. conducts long-term monitoring of shoreline erosion on the ocean side of the outer banks near Duck. The last intensive monitoring experiment was in 1997. More information about their research studies is available at http://www.frf.usace.army.mil/SandyDuck/SandyDuck.stm.

\section{Monitoring Gaps Identified for Beaches}

Currently, the only specific NMN criterion for beach monitoring is the microbial indicators. NCDMF is meeting the need to monitor recreational beaches for fecal contamination through routine testing for enterococci bacteria. Beaches represent an important resource in the region. The USFWS and NPS would be able to assist with beach monitoring and NMN design for biological assessments. The USACE could provide information and assist with designing a monitoring program for beach erosion.

\section{Nearshore Monitoring}

For the purpose of this report, nearshore ocean waters of the Albemarle Sound study region for the NMN consist of the Atlantic Ocean within 3 miles (mi) of Albemarle Sound beaches. This area is inside the Albemarle Sound study regional boundary shown in figure 11 .

Storm surge monitoring-In 2011, Hurricane Irene made landfall on the coast of North Carolina. Before the storm, storm-surge sensors were deployed with the assistance of North Carolina Sea Grant (Sea Grant storm surge sensors) and the USGS (USGS Irene). These sensors continuously monitored the storm surge during the passing of the storm and allowed scientists to better understand, track, and model the storm. Maps showing the location of the storm-surge sensors and the data collected, the location and heights of highwater marks, and the track of the hurricane, are available at http://wim.usgs.gov/stormtidemapper/stormtidemapper.html\# and $h t t p: / / v i m e o . c o m / 49126492$.

USACE - The USACE operates a field research facility in Duck, N.C. Instruments at the facility continuously monitor changes in waves, winds, tides, and currents from an onsite pier. In addition, the USACE operates wave gages that continuously measure nearshore salinity and temperature (USACE wave gage). An additional gage that measures waves, winds, tides, and currents is located south of the facility on another pier. In addition, the USACE has one nearshore buoy that measures wave height, period, and direction, wind speed, and water and air temperature $3 \mathrm{~km}$ west of the research station. All buoy data can be accessed at http://www.frf.usace.army.mil/frf.shtml.

$V A D E Q$ - VADEQ, with the assistance of the EPA, conducted a nearshore oceanic survey at 50 sites along the coastline of Virginia in 2010 (VADEQ nearshore). Six of these sites were located within the study area and physical profiles were taken at each of these six sites. In addition, nearsurface water-quality samples were collected for chlorophyll $a$, bacteria, trace metals, nutrients, and polycyclic-aromatic hydrocarbons. Sediment was sampled for particle-size distribution, total organic carbon, metals, organics, toxicity, and benthic communities. Data are currently housed in the VADEQ Comprehensive Environmental Data System Water Quality Monitoring (CEDS WQM) database, but there are plans to migrate the data to STORET. Data can be accessed by contacting VADEQ.

\section{Monitoring Gaps Identified for Nearshore}

Current monitoring does not meet the network design requirement for the nearshore environment. Continuous measurements of physical condition are available in one location at various distances from the nearshore at the USACE Duck Field Research Facility (FRF), but additional parameters, such as dissolved oxygen and $\mathrm{pH}$, could be added to their monitoring platform. In addition, initiatives such as the predeployed Hurricane Irene storm gages should be continued in the future to further our understanding of storm surge during hurricanes.

Nearshore monitoring of chemical and biological parameters in water and sediment was conducted in 2010 as part of a special study in Virginia. There is no current nearshore monitoring for nutrients, contaminants, and biological assessments in the water and sediment off the coast of North Carolina. If monitoring is established for North Carolina and continued for Virginia, both programs would need to increase the frequency of surveys to once a year in order to meet the NMN design.

\section{Offshore Monitoring}

For the purpose of this report, offshore monitoring includes any current monitoring being conducted east of the nearshore boundary. Sites southeast of the boundary also were included because the one inlet that allows exchange between the Atlantic Ocean and the Albemarle Sound, Oregon Inlet, is located at the southern end of the region.

Coastal Studies Institute-The University of North Carolina Coastal Studies Institute operates a buoy 10 nautical miles (nmi) east of Oregon Inlet (CSI wave gage). The buoy continuously monitors wave height, period, and direction. Data are available online at $h t t p: / / w w w . f r f . u s a c e$. army.mil/ waverdr192/realtime.shtml. 


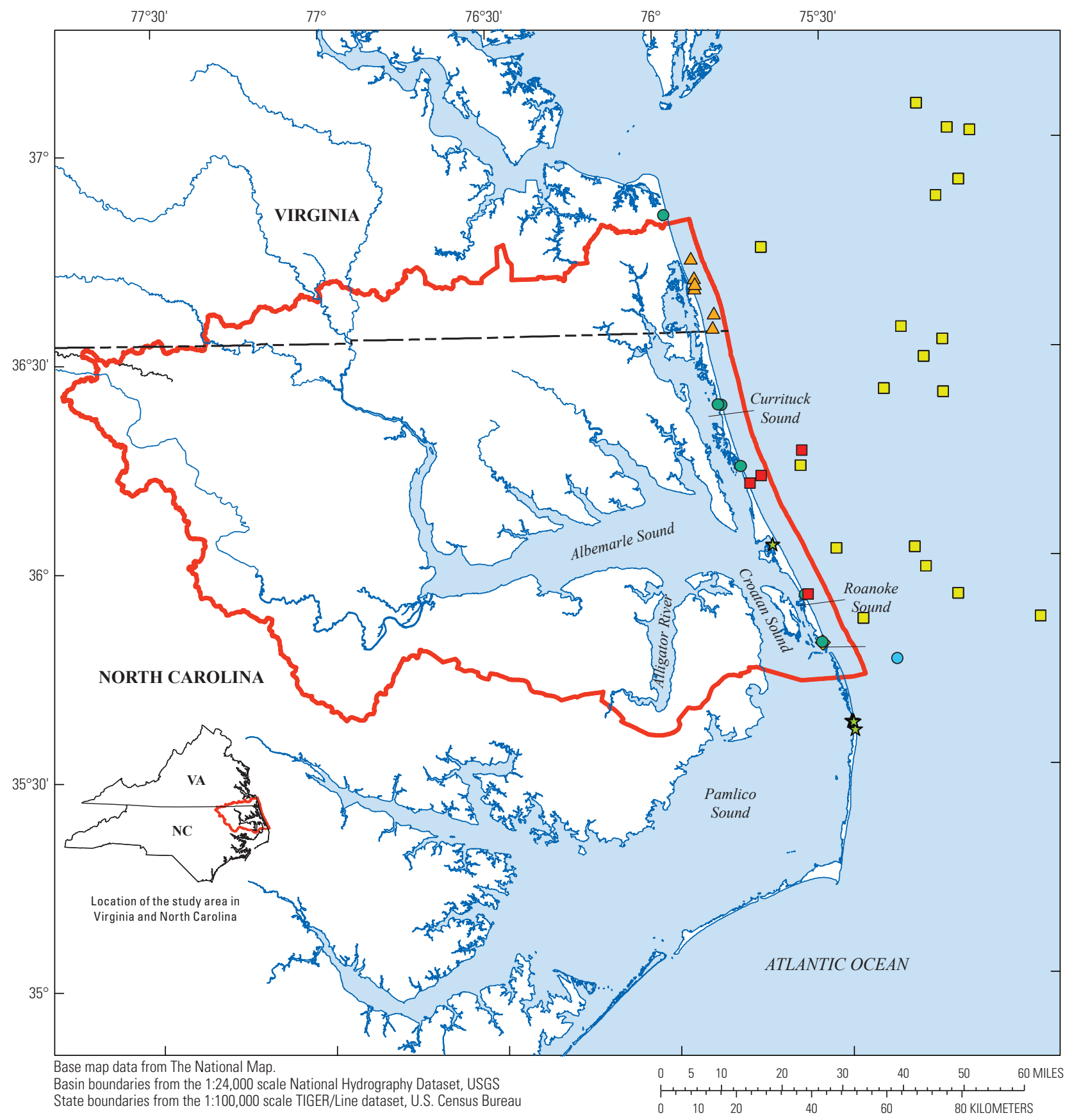

State boundaries from the 1:100,000 scale TIGER/Line dataset, U.S. Census Bureau

EXPLANATION

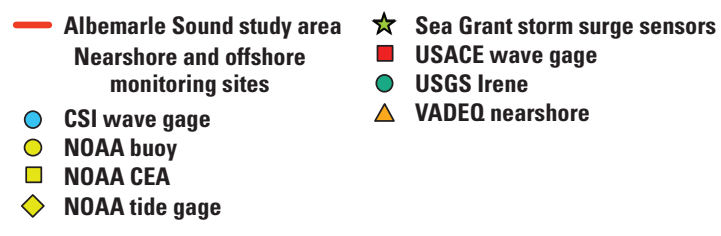

Figure 11. Nearshore and offshore monitoring in the Albemarle Sound region. [CEA, Coastal Ecological Assessments; CSI, Coastal Studies Institute; NOAA, National Oceanic and Atmospheric Administration; USACE, U.S. Army Corps of Engineers, USGS, U.S. Geological Survey; VADEQ, Virginia Department of Environmental Quality] 
NOAA-NOAA maintains one offshore buoy (NOAA buoy) that continuously monitors wave height, period, and direction, as well as atmospheric pressure, air temperature, and dewpoint at a station approximately 115 $\mathrm{km}$ east of Virginia Beach: http://www.ndbc.noaa.gov/station_page.php?station $=44014$. In 2004, NOAA conducted a series of coastal ecological assessments (NOAA CEA) in partnership with the USEPA to assess the condition of aquatic resources throughout coastal-ocean waters of the United States using multiple indicators of ecological condition. The protocols and design of these studies are similar to those used in the EPA National Coastal Assessment. Twenty-one sites were located offshore from Albemarle Sound (fig. 11). Water samples were analyzed for nutrients and chlorophyll $a$; physical profiles of the water column were recorded; sediment samples were analyzed for toxicity, metals, contaminants, total organic carbon, and benthic communities; and fish-tissue samples were analyzed for contaminants. Further information is available at http://www.chbr.noaa.gov/par/coastal_ecology.aspx.

\section{Monitoring Gaps Identified for Offshore}

Currently, there is no specific design for offshore monitoring. Instead the NMN deferred the task to the U.S. Integrated Ocean Observing System (IOOS) management unit. For the Albemarle Sound study region, this includes both Southeast Coastal Ocean Observing Regional Association (SECOORA) and Mid-Atlantic Coastal Ocean Observing Regional Association (MACOORA).

\section{Relevance of the National Monitoring Network (NMN) to Integrated Ocean Observing System (IOOS) and Other Regional Monitoring Assessments}

The design of the NMN explicitly states that it will compliment efforts of the Integrated Ocean Observing System (IOOS; ACWI and NWQMC, 2006). IOOS is a multidisciplinary system designed to provide ocean and coastal data in formats, scales, and rates required by users. Similar to the NMN, IOOS was strengthened as a result of the National Ocean Action Plan. The Ocean Action Plan (Executive Office of the President, 2004) was the government's response to reports on ocean policy by the U.S. Commission on Ocean Policy (2004) and Pew Oceans Commission (2003). Both reports recommended the development of entities designed to coordinate ocean information and increase data access and integration to improve the understanding and management of the oceans. The Ocean Commission report suggests that the NMN be closely linked with IOOS. Each of the eleven Regional Associations within IOOS works to address the overarching IOOS themes (http://www.ioos.noaa.gov/themes/welcome.html) and address more specific regional issues. Currently, IOOS is gathering these disparate Federal and non-Federal data sources into an integrated system, giving users access to data from many sources. In addition, IOOS is deploying new technology to fill in gaps in measurements and to ensure users have access to the best available information to support decisionmaking.

Components of the developing NMN are ideally suited to contribute to and enhance IOOS. As part of the NMN, Albemarle Sound Demonstration Study is a regional pilot for water-quality monitoring in the Southeast Coastal Ocean Observing Regional Association (SECOORA) region, one of the eleven IOOS regional associations. The NMN and SECOORA are working together to build a comprehensive and cost-effective monitoring program that shares information and resources, such as stakeholder assessments, system design ideas and proposals, known high priority issues and specific resource management goals, and data management strategies and systems. Comparable data and an integrative approach to ecosystem monitoring are essential so that data, data products, and online resources are provided in a consistent and integrated manner.

NMN-SECOORA collaboration presents an opportunity to build and improve relationships with State and Federal initiatives, specifically in terms of data management efforts. Existing data management initiatives at the State level, such as the North Carolina Coastal Atlas (https://www.nccoastalatlas.org/), the regional level, such as the Governors' South Atlantic Alliance (GSAA) Coast and Ocean Portal (http://www.gsaaportal.org/) and the Southeast Coastal Water Quality Monitoring Portal (http://www.gcrc.uga.edu/wqmeta/), and at the Federal level, such as the EPA Water Quality Exchange (http://www.epa.gov/storet/wqx/) database will benefit from, and compliment, efforts to implement the NMN. The information included in this report expands these efforts in the Albemarle Sound study region to gather more in-depth information about monitoring and research programs at the level of an individual estuarine system, the Albemarle Sound.

SECOORA has built a robust data management system that is complementary to the Albemarle Sound NMN. For example, SECOORA and their partners are building data and metadata inventory for the GSAA Portal that provides easy access to data and metadata for the four southeastern states (North Carolina, South Carolina, Georgia, and Florida). Sharing information collected as part of the NMN will enhance the development of data programs and eliminate redundant efforts. Beyond the metadata and data inventory, SECOORA data management efforts include an interactive data access server that provides users with historical and real-time data (http://secoora.org/data) and products associated with specific management issues. The work of the NMN can help identify datasets that could be served via the SECOORA portal. 


\section{Data Management and Access Challenges}

Coordinating data management efforts across organizational boundaries so that monitoring data are compatible is a challenge for the NMN. Different organizations utilize different analytical methods that have changed through time and data are stored in various databases that produce outputs that may not be directly compatible. Thus, it was important to identify data issues that would need to be addressed by the NMN if the goal is to meet the NMN design through monitoring efforts undertaken by multiple organizations.

\section{Data Comparability}

There can be issues of data compatibility when analyzing monitoring data from different organizations (NRC, 1995; ACWI, 2001; GAO, 2004). Organizations may use different sampling and analytical methods and may have different method detection limits (MDLs) and reporting limits (RLs). Nutrients are one of the most commonly monitored parameters in the estuarine system. An investigator may want to utilize multiple datasources to conduct a thorough analysis of nutrient concentrations in the estuarine system, which might require data from multiple organizations. In order to do this, the researcher must address any bias in the analysis from differences that exist between organizational sampling, laboratory, and reporting protocols. This would include

1. Comparing field methods and protocols to make sure that samples are collected using comparable techniques; for example, results from a water-quality sample from the estuary that only captures the photic zone would be different than a sample that integrates over the entire water column;

2. Comparing laboratory methods to ensure compatible laboratory techniques are used to obtain values for a constituent because multiple laboratory methods may be available;

3. Comparing reporting limits, which includes understanding the method detection limits for the laboratory and the reporting limits for the laboratory; different method detection and reporting limits could artificially bias analysis; and

4. Collecting quality-assurance data, including split replicates from all labs from which data will be analyzed to compare between-lab bias when possible (NWQMC, 2006).

\section{Data Access}

Prior to this study, there was no central location to access information about current monitoring programs in the Albemarle Sound study region. Thus, we asked individual monitoring agencies to provide detailed information about data access, management, and delivery as part of our survey. This information is summarized by the lumped projects that have been coded by RepName in table 6 . Not all organizations responding to the survey provided information. The survey results indicated that most monitoring programs keep their data in a digital format that are managed in a database, although some monitoring data from earlier programs are available in paper copy only. Not all data are publically available on the Internet, even if data are in a database. For these programs, a request for the data needs to be made to the monitoring agency. Currently, EPA is the only program to fully comply with the Advisory Committee on Water Information (ACWI) metadata standards (NWQMC, 2006). Only 15 percent of the programs partially comply, whereas 4 percent of the programs are not documented and 75 percent of the programs only have general documentation for the database as a whole. Fifty-four percent of the programs have data archived in redundant systems located in multiple geographic locations.

\section{Solutions for Improving Data Access}

Several agencies, such as the USFWS and VADEQ, are working to improve data access, management, and delivery. Currently, the USFWS is entering monitoring information into a central database known as the Priority Refuge Inventory and Monitoring Report (PRIMR) database. Once this task is completed, the USFWS and other interested parties will be able to generate summary reports of individual inventory and monitoring projects on NWRs. The USFWS is using an application called ServCat (Service Catalog) to create records associated with the refuges, complete with metadata from documents, such as reports, surveys, databases, geospatial data and images. Once ServCat is fully functional, the information will be retrievable using text or geospatial search tools.

VADEQ is currently working on moving their water- and sediment-quality data from the Comprehensive Environmental Data System Water Quality Monitoring (CEDS WQM) database system to the USEPA's STORET database. The Water Quality Portal is a cooperative service sponsored by the USGS, USEPA, and the National Water Quality Monitoring Council. This Web-based portal allows queries of USEPA and USGS water-quality databases simultaneously (http://www.waterqualitydata.us/). The query output from both databases is consistent in format and nomenclature, allowing for improved sharing of data between partner agencies. For this reason, it would be useful for any agencies collecting water-quality data that are not being stored in USEPA's STORET database to work with the USEPA to migrate their water-quality data into this database.

As a result of the Albemarle Pilot NMN, East Carolina University/UNC Coastal Studies Institute (ECU/CSI) and the USGS have developed a plan to support the sharing of data in the Albemarle Sound study region though (1) migrating discrete water-quality data previously collected by local and State entities into the USEPA Exchange Network Discovery 
Table 6. Data access, management and delivery by report name.

[Data not reported for all programs. ACWI, Advisory Committee on Water Information; STORET, STOrage and RETrieval; VADEQ, Virginia Department of Environmental Quality]

\begin{tabular}{|c|c|c|c|}
\hline Access method (56 reporting) & Definition & $\begin{array}{c}\text { Number of } \\
\text { programs }\end{array}$ & $\begin{array}{l}\text { Percentage of } \\
\text { all programs }\end{array}$ \\
\hline Not available & Access is limited to the originator and close collaborators. & 1 & 2 \\
\hline Digital & $\begin{array}{l}\text { Data are available in a tab-delimited or regularly-formatted } \\
\text { structure, and may be selected for such elements as location } \\
\text { and time. }\end{array}$ & 52 & 93 \\
\hline Web services & Available for automatic machine-to-machine transfers. & 2 & 4 \\
\hline \multicolumn{4}{|c|}{ Search and retrival method (56 reporting) } \\
\hline Hidden & Data can not be found by conventional searches. & 19 & 16 \\
\hline Portal & $\begin{array}{l}\text { "The user may discover the existence of a database, but must gain } \\
\text { access to the individual database to make further queries." }\end{array}$ & 5 & 9 \\
\hline Location-value & The user may discover sampling sites; result values are available. & 41 & 73 \\
\hline \multicolumn{4}{|c|}{ Metadata level (52 reporting; NWQMC, 2006) } \\
\hline Undocumented & & 2 & 4 \\
\hline Database & $\begin{array}{l}\text { Metadata available for database as a whole but individual entries } \\
\text { have minimal documentation. }\end{array}$ & 39 & 75 \\
\hline ACWI-partial & Partial compliance with ACWI standards & 8 & 15 \\
\hline ACWI-full & Full compliance with ACWI standards & 3 & 6 \\
\hline \multicolumn{4}{|c|}{ Archive method (46 reporting) } \\
\hline
\end{tabular}

${ }^{1}$ VADEQ is working to get all their data entered into the STORET systems in 2013.

Service (ENDS), particularly the Water Quality Exchange (WQX); (2) migrating continuous and real-time waterquality data collected by ECU/CSI into NWIS Web; and (3) training key local, State, and national partners on how these data can be used to improve environmental management of the estuary. For this last point, ECU/CSI and USGS plan to educate a broad community of managers and experts on how best to retrieve and analyze data from ENDS and NWIS Web using existing mobile and desktop applications and Web sites. ECU/CSI and USGS plan to provide interactive, user-friendly environmental information including real-time estuary updates and trend analysis for the Albemarle Sound study region. As an added benefit, the USGS will analyze the feasibility of registering continuous and real-time NWIS Web data into ENDS using the knowledge obtained from the migration of discrete partner data to ENDS.

\section{Summary and Major Conclusions from Pilot Study}

Currently, there are many collaborative planning initiatives underway by resource-management agencies in the Albemarle region such as U.S. Fish and Wildlife Service, AlbemarlePamlico National Estuary Partnership, North Carolina Division of Marine Fisheries, and the Governor's South Atlantic Alliance. These programs have the goal of improving current understanding of important resource-management issues and the management approaches to resolving these issues. Three management 
goals with a high priority include (1) protecting important estuarine habitat including submerged aquatic vegetation and wetlands, (2) planning and preparing for sea-level rise and its associated impacts on coastal communities and natural resources, and (3) insuring the estuary remains a healthy and productive ecosystem that can support a healthy fishery. All management plans specify monitoring as a needed component of resource management. The information from this report can help provide guidance about the monitoring data available and additional monitoring needed in order to improve natural resource management.

This report suggests there are important monitoring activities occurring in the Albemarle Sound, but that there are a number of enhancements that must be made to meet the criteria of the National Monitoring Network (NMN) design (table 7). Information about current monitoring programs and identified research gaps provided in this report will help coordinate further monitoring activities in the region. Several activities have been initiated as part of this demonstration project. One of the identified data gaps was an incomplete monitoring NMN design in the estuaries and rivers for nutrients, phytoplankton communities, contaminants, and continuous real-time measurements of physical parameters in the Albemarle Sound. As part of the demonstration project, we have implemented a monitoring program to address this gap by

1. Monitoring contaminants, such as pesticides, metals, nutrients, sediment, and algal toxins, in the water column at 33 sites distributed throughout the sound and metals in the sediment at 20 sites distributed throughout the sound in 2012;

2. Analyzing 2012 monitoring data to identify parameters in exceedance of regulatory limits or National Oceanic and Atmospheric Administration guidelines to design additional sampling in 2013;

3. Monitoring nutrients and sediment on a monthly basis from March 2013 to February 2013 at seven sites in unmonitored embayments and measuring pesticides, phytoplankton communities, and algal toxins once per season at 12 sites in the sound;

4. Working with North Carolina Division of Water Resources (NCDWR) to assess data compatibility between U.S. Geological Survey and NCDWR data for the purpose of creating a complimentary network of nutrient monitoring; and

5. Using this project to help plan for the implementation of other important water-quality projects in the sound such as the development of a real-time continuous monitoring network of water levels and other water-quality parameters of concern, such as low dissolved oxygen and elevated $\mathrm{pH}$.

In addition, a need to synthesize existing local and regional monitoring data to the scale of the entire Albemarle Sound area has been identified. Many of the monitoring programs active in the region are programs that synthesize information on a national or regional basis. Other State datasets date back to the late 1970s and early 1980s and, therefore, have the ability to show trends in estuary water quality since the implementation of the Clean Water Act. A long-term trends analysis of the estuary hasn't been conducted since 1990, however (Harned and Davenport, 1990). Thus, one perceived data gap is the lack of a recent compilation and synthesis of water-quality information at the scale of the Albemarle Sound study region. This task is being accomplished with the assistance of graduate students at Duke University as part of its Master of Environmental Management Program. Lastly, we believe it would be useful to expand the efforts of the NMN to other estuaries in the region with a priority system being the Pamlico Sound, which constitutes the Southern half of the AlbemarlePamlico estuarine system, because most planning initiatives focus on the Albemarle-Pamlico Sound as one resource unit.

In summary, this demonstration project has shown the benefits of the NMN design in an estuarine system that is not urban in nature. This presents its own challenges and makes the Albemarle Sound atypical among the demonstration projects because it is less studied then the more urban estuarine systems such as Puget Sound, San Francisco Bay, Delaware Bay, or the Great Lakes. Thus, one of the greatest benefits of this project was the synthesis of monitoring and research efforts in the region. In addition, this effort has highlighted the data sets and data gaps in the Albemarle Sound study area and can help guide future monitoring initiatives. 
Table 7. Recommendations for National Monitoring Network enhancements in the Albemarle Sound region.

[NCDMF, North Carolina Division of Marine Fisheries; ECU, East Carolina University; NCDWR, North Carolina Division of Water Resources; NADP, National Atmospheric Deposition Program; USFWS, U.S. Fish and Wildlife Service; USACE, U.S. Army Corps of Engineers; NPS, National Park Service; IOOS, Integrated Ocean Observing System]

Resource component

Estuaries and rivers: nutrients

Estuaries and rivers: physical parameters

Estuaries and rivers: contaminants

Estuaries and rivers: biology

Groundwater

Atmospheric deposition

Wetlands

Beaches

Nearshore

\section{Recommended enhancement}

Nutrient monitoring should be enhanced by monitoring additional sites on a monthly basis once every five years. Additional monitoring should target unmonitored embayments. Additional analytes may be needed, especially in Virginia. The deployment of real-time sensors should be considered.

The continuous, real-time network should be expanded in the Albemarle Sound region to include inputs from major rivers and inflows and to cover sites at the head and mouth of the estuary for all physical parameters (water level, wave height, flow, temperature, $\mathrm{pH}$, dissolved oxygen, salinity/conductance). Specifically, a sites should be added on the mouth of the Chowan River and in the western Albemarle. NCDMF's continuous montoring network should be upgraded to a real-time system. ECU's proposed real-time network should be implemented to improve monitoring in the Eastern Albemarle.

Periodic surveys of contaminants in the waters of the estuary and rivers is needed.

Routine monitoring of phytoplankton and invertebrates in the estuary is needed.

NCDWR could sample nutrients once every 2-3 years when they sample chloride in shallow aquifer systems

The NADP network meets the network design for atmospheric deposition, but could be enhanced by adding an ammonia deposition site within the study boundary.

USFWS could lead the design of a region specific wetland monitoring network

USACE could lead design of monitoring program for beach erosion, USFWS and NPS could lead design of beach biological assessments.

Addition of water-quality parameters such as dissolved oxygen and $\mathrm{pH}$ could be added to the real-time network, storm-surge monitoring should be continued, nutrients, contaminants and biological assessments in the water and sediment off the coast of North Carolina and Virginia should be conducted annually. 


\section{References Cited}

Advisory Committee on Water Information (ACWI), 2001, Resolution of the Advisory Committee on Water Information adopting the data elements for reporting water quality results of chemical and microbiological analytes: Accessed March 15, 2013, at http://acwi.gov/acwi2001/ resolution_wqde01.html.

Advisory Committee on Water Information and the National Water Quality Monitoring Council (ACWI and NWQMC), 2006, A national water quality monitoring network for U.S. coastal waters and their tributaries: Accessed March 1, 2013, at http://acwi.gov/monitoring/network/ design/.

Albemarle-Pamlico National Estuary Partnership (APNEP), 2012, Comprehensive Conservation and Management Plan 2012-2022: Accessed July 1, 2012, at http://portal.ncdenr. org/web/apnep/ccmp.

Bales, J.D., and Nelson, T.M., 1988, Bibliography of hydrologic and water-quality investigations conducted in or near the Albemarle-Pamlico Sounds region, North Carolina: U.S. Geological Survey Open-File Report 88-480, 148 p.

Boon, J.D., 2012, Evidence of sea level acceleration at U.S. and Canadian tide stations, Atlantic Coast, North America: Journal of Coastal Research, v. 28, no. 6, p. 1437-1445.

Bricker, S., Longstaff, B., Dennison, W., Jones, A., Boicourt, K., Wicks, C., and Woerner, J., 2007, Effects of nutrient enrichment in the Nation's estuaries-A decade of change: Silver Spring, Md., National Oceanic and Atmospheric Administration, Coastal Ocean Program Decision Analysis Series no. 26, National Centers for Coastal Ocean Science, 322 p. (Also available at $h t t p: / / c c m a . n o s . n o a a . g o v /$ publications/eutroupdate/.)

Burnett, W.C., Aggarwal, P.K., Aureli, A., Bokuniewicz, H., Cable, J.E., Charette, M.E., Kontar, E., Krupa, S., Kulkarni, K.M., Loveless, A., Moore, W.S., Oberdorfer, J.A., Oliveira, J., Ozyurt, N., Povinec, P., Privitera, A.M.G., Rajar, R., Ramessur, R.T., Scholten, J., Stieglitz, T., Taniguchi, M., and Turner, J.V., 2006, Quantifying submarine groundwater discharge in the coastal zone via multiple methods: Science of the Total Environment, v. 367, p. 498-543.

Carpenter, D.E., and Dubbs L., 2012, 2012 AlbemarlePamlico Ecosystem Assessment, Albemarle-Pamlico National Estuary Partnership: Accessed November 15, 2013, at http://portal.ncdenr.org/c/ document_library/get_file?uuid $=1 c 126 d 0 c-2589-40 c 7$ ac41-125f99ad0c70\& groupId $=61563$.
Currin, C.A., Chappell, W.S, and Deaton, A., 2010, Developing alternative shoreline armoring strategies-The living shoreline approach in North Carolina, in Shipman, H., Dethier, M.N., Gelfenbaum, G., Fresh, K.L., and Dinicola, R.S., eds., 2010, Puget Sound Shorelines and the Impacts of Armoring - Proceedings of a State of the Science Workshop, May 2009: U.S. Geological Survey Scientific Investigations Report 2010-5254, p. 91-102.

Deaton, A.S., Chappell, W.S., Hart, K., O`Neal, J., and Boutin, B., 2010, North Carolina Coastal Habitat Protection Plan: North Carolina Department of Environment and Natural Resources, Division of Marine Fisheries, 639 p.

Executive Office of the President, 2004, U.S. Ocean Action Plan-The Bush Administration's response to the U.S. Ocean Commission on Policy: Executive Office of the President of the United States, 39 p., accessed March 31, 2014, at $\mathrm{h} t t p: / / w w w . n a u t i c a l c h a r t s . n o a a . g o v / o c s / h s r p / a d m i n /$ mar2005/OceanActionPlan.pdf

Ezer, T., Atkinson, L.P., Corlett, W.B., and Blanco, J.L., 2013, Gulf Stream's induced sea level rise and variability along the U.S. Mid-Atlantic Coast: Journal of Geophysical Research Oceans, v. 118, p. 685-697, accessed April 1, 2014, at http://dx.doi.org/10.1002/jgrc.20091.

Fry, J., Xian, G., Jin, S., Dewitz, J., Homer, C., Yang, L., Barnes, C., Herold, N., and Wickham, J., 2011, Completion of the 2006 National Land Cover Database for the conterminous United States: Photogrammetric Engineering \& Remote Sensing, v. 77, p. 858-864.

General Accounting Office (GAO), 2004, Watershed management-Better coordination of data collection efforts: GAO-04-382, accessed November 15, 2013, at http://www.gao.gov/new.items/d04382.pdf.

Giese, G.L., Wilder, H.B., and Parker, G.G., Jr., 1985, Hydrology of major estuaries and sounds of North Carolina: U.S. Geological Survey Water-Supply Paper 2221, 108 p.

Harned, D.A., and Davenport, M.S., 1990, Water-quality trends and basin activities and characteristics for the Albemarle-Pamlico estuarine system, North Carolina and Virginia: U.S. Geological Survey Open-File Report 90-398, $164 \mathrm{p}$.

National Water Quality Monitoring Council (NWQMC), 2006, Data elements for reporting water quality monitoring results for chemical, biological, toxicological, and microbiological analytes: Methods and Data Comparability Board of the National Water Quality Monitoring Council, NWQMC Technical Report no. 3, accessed April 15, 2013, at http://acwi.gov/methods/pubs/wdqe_pubs/wqde_trno3.pdf. 
National Research Council (NRC), 1995, Finding the forest in the trees-The challenge of combining diverse environmental data: Washington, D.C., National Academy Press, accessed November 15, 2013, at http://www.nap.edu/ openbook $/ 0309050820 / \mathrm{html} / 1 . \mathrm{html}$.

North Carolina Department of Environment and Natural Resources (NCDENR), 2014, North Carolina nutrient criteria development plan, v. 2.0.

North Carolina Sea Grant, 1997, Coastal water quality: Raleigh, North Carolina State University, UNC-SG-97-04, $72 \mathrm{p}$.

Pew Oceans Commission, 2003, America's living oceans: Arlington, Va., Pew Oceans Commission, accessed April 15, 2012, at http://www.pewtrusts.org/uploadedFiles/ wwwpewtrustsorg/Reports/Protecting_ocean_life/POC_ Summary.pdf.

PRISM Climate Group, 2012, United States average annual precipitation, 1981-2010: Corvallis, Oregon State University, accessed November 15, 2013, at http://prism.oregonstate.edu.

Sallenger, A.H., Jr., Doran, K.S., and Howd, P.A., 2012, Hotspot of accelerated sea-level rise on the Atlantic Coast of North America: Nature Climate Change, v. 2, p. 884-888, accessed November 15, 2013, at http://dx.doi.org/10.1038/ nclimate1597.
U.S. Commission on Ocean Policy, 2004, Creating a National Monitoring Network, chap. 15 of An ocean blueprint for the 21st Century: Final Report of the U.S. Commission on Ocean Policy, Washington, D.C., accessed March 31, 2014, at http://govinfo.library.unt.edu/oceancommission/documents/full_color_rpt/welcome.html.

U.S. Environmental Protection Agency, 2009, National Lakes Assessment-A collaborative survey of the Nation's lakes: Washington, D.C., U.S. Environmental Protection Agency Report EPA 841-R-09-001, accessed March 1, 2013, at http://www.epa.gov/owow/LAKES/lakessurvey/pdf/ nla_report_low_res.pdf.

U.S. Fish and Wildlife Service, 2008, Strategic habitat conservation handbook - A guide to implementing the technical elements of strategic habitat conservation (version 1.0): Accessed November 21, 2013, at http://www.fws.gov/ landscape-conservation/pdf/SHCHandbook.pdf. 


\section{Appendix 1}

Table 1-1. Data dictionary.

[ID, identifier, USGS, U.S. Geological Survey; QAQC, quality assurance quality control; URL, uniform resource locator; NWIS, National Water Information System]

\begin{tabular}{|c|c|c|}
\hline Table heading & Table name & Description \\
\hline OID & Object identifier & Unique identifier for each entry \\
\hline SampNo & Sample number & $\begin{array}{l}\text { Unique ID for each sample type that relates location data to metadata through the } \\
\text { field SampNo }\end{array}$ \\
\hline ReportNm & Report name & Acronym used to identify sample in USGS companion report \\
\hline ProjName & Project name & Name of project. \\
\hline ShortNm & Project shortname & Provides an acronym that can be used to reference the project. \\
\hline SampName & Project sample name & $\begin{array}{l}\text { A short descriptive name that can be used to reference distinct groups of samples } \\
\text { for projects or organizations. Sample groups are distinctive by the frequency } \\
\text { of their collection, the media type, and the event type. }\end{array}$ \\
\hline Cnt_Samp & Count of samples & Number of sites related to SampName \\
\hline PrjObj & Project objective & A text description of the purpose of the project. \\
\hline Website & Web site & A list of any websites describing the project. \\
\hline StrtDate & Project start date & The approximate date the project started. \\
\hline EndDate & Project end date & The approximate date the project ended. \\
\hline Comments & Comments & Additional comments supplied during data entry. \\
\hline ResComp & Resource compartment & This field allows the user to specify which resource compartment was sampled. \\
\hline RiverEstua & River or estuary & Uses boolean logic $(1=$ true $)$ to identify samples collected in rivers or estuaries. \\
\hline NutSamp & Nutrient sample & Uses boolean logic $(1=$ true $)$ to identify nutrient samples. \\
\hline PhysSamp & Physical sample & Uses boolean logic $(1=$ true $)$ to identify continuous physical samples. \\
\hline ContSamp & Contaminant sample & Uses boolean logic $(1=$ true $)$ to identify contaminant samples. \\
\hline BioSamp & Biological sample & Uses boolean logic $(1=$ true $)$ to identify biological samples. \\
\hline PathSamp & Pathogen sample & Uses boolean logic $(1=$ true $)$ to identify pathogen samples. \\
\hline RepOrg & Report organization & Report acronym for the organization collecting the sample. \\
\hline Org & Organization & The organization(s) responsible for the project. \\
\hline Div & Division & This is an organization division code \\
\hline LastName & Last name & The last name of the project contact. \\
\hline FrstName & First name & The first name of the project contact. \\
\hline Phone & Phone number & The phone number of the contact for the project \\
\hline Email & Email address & The email address of the contact for the project \\
\hline MediaTyp & Media type & This field discusses the type of media sampled. \\
\hline EvntType & Event type & $\begin{array}{l}\text { This field discusses the type of sample event, usually either discrete, continuous, } \\
\text { or remotely sensed. }\end{array}$ \\
\hline StudyTyp & Study type & $\begin{array}{l}\text { This field discusses the type of study, i.e. either long-term monitoring or short- } \\
\text { term study and whether or not the study is active. }\end{array}$ \\
\hline Monitor & Monitoring program & $\begin{array}{l}\text { This field uses Boolean logic }(1=\text { true }) \text { to specify if the programs is defined as a } \\
\text { long-term monitoring program, i.e. is greater than } 3 \text { years in duration. }\end{array}$ \\
\hline Study & Study & $\begin{array}{l}\text { This field uses Boolean logic }(1=\text { true }) \text { to specify if the programs is defined as a } \\
\text { study, i.e. is less than } 3 \text { years in duration. }\end{array}$ \\
\hline Active & Status & This field uses Boolean logic $(1=$ true $)$ to specify if the program is active. \\
\hline FreqDesc & Frequency description & $\begin{array}{l}\text { Provide a brief description of the sampling scheme (i.e. weekly during the sum- } \\
\text { mer and monthly during the winter or only during high flow events). }\end{array}$ \\
\hline SampProc & Sample procedures & $\begin{array}{l}\text { Please provide a link or attach any documentation that describes how the data is } \\
\text { collected. }\end{array}$ \\
\hline Database & Data management system & $\begin{array}{l}\text { This describes where the project data resides. Examples include: NWIS, Storet, } \\
\text { Access, Excel spreadsheet }\end{array}$ \\
\hline
\end{tabular}


Table 1-1. Data dictionary.-Continued

[ID, identifier, USGS, U.S. Geological Survey; QAQC, quality assurance quality control; URL, uniform resource locator; NWIS, National Water Information System]

\begin{tabular}{|c|c|c|}
\hline Table heading & Table name & Description \\
\hline DataLink & Data link & This is a URL to where the data can be accessed on-line \\
\hline DataAcc & Data access method & Provides information on how data can be accessed online. \\
\hline SearchRM & Search retrieval method & Provides information on how data can be retrieved. \\
\hline MdataLvl & Metadata level & Provides informatioin on project metadata \\
\hline ArchiveM & Archive method & Provides information on how data is archived \\
\hline qaqc_rep & QAQC rep & Mark yes if replicates were sampled \\
\hline qaqc_mat & QAQC matrix & Mark yes if matrix spikes were sampled. \\
\hline qaqc_blk & QAQC blank & Mark yes if blank samples were collected. \\
\hline qaqc_spl & QAQC split & Mark yes if splits were sampled. \\
\hline Algae & Algae & $\begin{array}{l}\text { Uses Boolean logic to determine if parameter collected as part of sample (values } \\
\text { of } 1=\text { true). }\end{array}$ \\
\hline Bacteria & Bacteria & $\begin{array}{l}\text { Uses Boolean logic to determine if parameter collected as part of sample (values } \\
\text { of } 1=\text { true). }\end{array}$ \\
\hline Chla & Chlorophyll a & $\begin{array}{l}\text { Uses Boolean logic to determine if parameter collected as part of sample (values } \\
\text { of } 1=\text { true). }\end{array}$ \\
\hline Fish & Fish & $\begin{array}{l}\text { Uses Boolean logic to determine if parameter collected as part of sample (values } \\
\text { of } 1=\text { true). }\end{array}$ \\
\hline MacroIn & Macroinvertebrates & $\begin{array}{l}\text { Uses Boolean logic to determine if parameter collected as part of sample (values } \\
\text { of } 1=\text { true). }\end{array}$ \\
\hline Oysters & Oysters & $\begin{array}{l}\text { Uses Boolean logic to determine if parameter collected as part of sample (values } \\
\text { of } 1=\text { true). }\end{array}$ \\
\hline Parasite & Parasites & $\begin{array}{l}\text { Uses Boolean logic to determine if parameter collected as part of sample (values } \\
\text { of } 1=\text { true). }\end{array}$ \\
\hline PrimProd & Primary production & $\begin{array}{l}\text { Uses Boolean logic to determine if parameter collected as part of sample (values } \\
\text { of } 1=\text { true). }\end{array}$ \\
\hline Viruses & Viruses & $\begin{array}{l}\text { Uses Boolean logic to determine if parameter collected as part of sample (values } \\
\text { of } 1=\text { true). }\end{array}$ \\
\hline ChmInorg & Other - chemical inorganic & $\begin{array}{l}\text { Uses Boolean logic to determine if parameter collected as part of sample (values } \\
\text { of } 1=\text { true). }\end{array}$ \\
\hline ChmOrg & Other - chemical organic & $\begin{array}{l}\text { Uses Boolean logic to determine if parameter collected as part of sample (values } \\
\text { of } 1=\text { true). }\end{array}$ \\
\hline MajorIon & Major ions & $\begin{array}{l}\text { Uses Boolean logic to determine if parameter collected as part of sample (values } \\
\text { of } 1=\text { true). }\end{array}$ \\
\hline TrcElem & Trace elements & $\begin{array}{l}\text { Uses Boolean logic to determine if parameter collected as part of sample (values } \\
\text { of } 1=\text { true). }\end{array}$ \\
\hline Metals & Metals and metaloids & $\begin{array}{l}\text { Uses Boolean logic to determine if parameter collected as part of sample (values } \\
\text { of } 1=\text { true). }\end{array}$ \\
\hline NH4 & Dissolved ammonium & $\begin{array}{l}\text { Uses Boolean logic to determine if parameter collected as part of sample (values } \\
\text { of } 1=\text { true). }\end{array}$ \\
\hline NO2_NO3 & Dissolved nitrate plus nitrite & $\begin{array}{l}\text { Uses Boolean logic to determine if parameter collected as part of sample (values } \\
\text { of } 1=\text { true). }\end{array}$ \\
\hline PO4 & Dissolved ortho phosphate & $\begin{array}{l}\text { Uses Boolean logic to determine if parameter collected as part of sample (values } \\
\text { of } 1=\text { true). }\end{array}$ \\
\hline DissSi & Dissolved silica & $\begin{array}{l}\text { Uses Boolean logic to determine if parameter collected as part of sample (values } \\
\text { of } 1=\text { true). }\end{array}$ \\
\hline PartP & Particulate phosphorus & $\begin{array}{l}\text { Uses Boolean logic to determine if parameter collected as part of sample (values } \\
\text { of } 1=\text { true). }\end{array}$ \\
\hline DissN & Total dissolved nitrogen & $\begin{array}{l}\text { Uses Boolean logic to determine if parameter collected as part of sample (values } \\
\text { of } 1=\text { true). }\end{array}$ \\
\hline DissP & Total dissolved phosphorus & $\begin{array}{l}\text { Uses Boolean logic to determine if parameter collected as part of sample (values } \\
\text { of } 1=\text { true). }\end{array}$ \\
\hline $\mathrm{TN}$ & Total nitrogen & $\begin{array}{l}\text { Uses Boolean logic to determine if parameter collected as part of sample (values } \\
\text { of } 1=\text { true). }\end{array}$ \\
\hline
\end{tabular}


Table 1-1. Data dictionary.-Continued

[ID, identifier, USGS, U.S. Geological Survey; QAQC, quality assurance quality control; URL, uniform resource locator; NWIS, National Water Information System]

\begin{tabular}{|c|c|c|}
\hline Table heading & Table name & Description \\
\hline $\mathrm{TP}$ & Total phosphorus & $\begin{array}{l}\text { Uses Boolean logic to determine if parameter collected as part of sample (values } \\
\text { of } 1=\text { true). }\end{array}$ \\
\hline Alk & Alkalinity & $\begin{array}{l}\text { Uses Boolean logic to determine if parameter collected as part of sample (values } \\
\text { of } 1=\text { true). }\end{array}$ \\
\hline CondSal & Conductivity/Salinity & $\begin{array}{l}\text { Uses Boolean logic to determine if parameter collected as part of sample (values } \\
\text { of } 1=\text { true). }\end{array}$ \\
\hline DO & Dissolved oxygen & $\begin{array}{l}\text { Uses Boolean logic to determine if parameter collected as part of sample (values } \\
\text { of } 1=\text { true). }\end{array}$ \\
\hline OtherQW & $\begin{array}{l}\text { Other - water quality charac- } \\
\text { teristics }\end{array}$ & $\begin{array}{l}\text { Uses Boolean logic to determine if parameter collected as part of sample (values } \\
\text { of } 1=\text { true). }\end{array}$ \\
\hline $\mathrm{pH}$ & $\mathrm{pH}$ & $\begin{array}{l}\text { Uses Boolean logic to determine if parameter collected as part of sample (values } \\
\text { of } 1=\text { true). }\end{array}$ \\
\hline BulkOrg & Bulk organics & $\begin{array}{l}\text { Uses Boolean logic to determine if parameter collected as part of sample (values } \\
\text { of } 1=\text { true). }\end{array}$ \\
\hline DIC & Dissolved inorganic carbon & $\begin{array}{l}\text { Uses Boolean logic to determine if parameter collected as part of sample (values } \\
\text { of } 1=\text { true). }\end{array}$ \\
\hline DOC & Dissolved organic carbon & $\begin{array}{l}\text { Uses Boolean logic to determine if parameter collected as part of sample (values } \\
\text { of } 1=\text { true). }\end{array}$ \\
\hline PIC & Particulate inorganic carbon & $\begin{array}{l}\text { Uses Boolean logic to determine if parameter collected as part of sample (values } \\
\text { of } 1=\text { true). }\end{array}$ \\
\hline POC & Particulate organic carbon & $\begin{array}{l}\text { Uses Boolean logic to determine if parameter collected as part of sample (values } \\
\text { of } 1=\text { true). }\end{array}$ \\
\hline TOC & Total organic carbon & $\begin{array}{l}\text { Uses Boolean logic to determine if parameter collected as part of sample (values } \\
\text { of } 1=\text { true). }\end{array}$ \\
\hline EmgCont & Emerging Contaminants & $\begin{array}{l}\text { Uses Boolean logic to determine if parameter collected as part of sample (values } \\
\text { of } 1=\text { true). }\end{array}$ \\
\hline HalHC & Halogenated hydrocarbons & $\begin{array}{l}\text { Uses Boolean logic to determine if parameter collected as part of sample (values } \\
\text { of } 1=\text { true). }\end{array}$ \\
\hline Pest & Pesticides & $\begin{array}{l}\text { Uses Boolean logic to determine if parameter collected as part of sample (values } \\
\text { of } 1=\text { true). }\end{array}$ \\
\hline PCBs & Polychlorinated biphenyls & $\begin{array}{l}\text { Uses Boolean logic to determine if parameter collected as part of sample (values } \\
\text { of } 1=\text { true). }\end{array}$ \\
\hline PAHs & $\begin{array}{l}\text { Polycyclic aromatic hydrocar- } \\
\text { bons }\end{array}$ & $\begin{array}{l}\text { Uses Boolean logic to determine if parameter collected as part of sample (values } \\
\text { of } 1=\text { true). }\end{array}$ \\
\hline VOCs & Volatile organic carbons & $\begin{array}{l}\text { Uses Boolean logic to determine if parameter collected as part of sample (values } \\
\text { of } 1=\text { true). }\end{array}$ \\
\hline Depth & Depth & $\begin{array}{l}\text { Uses Boolean logic to determine if parameter collected as part of sample (values } \\
\text { of } 1=\text { true). }\end{array}$ \\
\hline Discharg & Discharge & $\begin{array}{l}\text { Uses Boolean logic to determine if parameter collected as part of sample (values } \\
\text { of } 1=\text { true). }\end{array}$ \\
\hline GWFlow & Groundwater flow & $\begin{array}{l}\text { Uses Boolean logic to determine if parameter collected as part of sample (values } \\
\text { of } 1=\text { true). }\end{array}$ \\
\hline TideHt & Tide height & $\begin{array}{l}\text { Uses Boolean logic to determine if parameter collected as part of sample (values } \\
\text { of } 1=\text { true). }\end{array}$ \\
\hline H20Lvl & Water level & $\begin{array}{l}\text { Uses Boolean logic to determine if parameter collected as part of sample (values } \\
\text { of } 1=\text { true). }\end{array}$ \\
\hline WindDir & Wind direction & $\begin{array}{l}\text { Uses Boolean logic to determine if parameter collected as part of sample (values } \\
\text { of } 1=\text { true). }\end{array}$ \\
\hline Info & Information & $\begin{array}{l}\text { Uses Boolean logic to determine if parameter collected as part of sample (values } \\
\text { of } 1=\text { true). }\end{array}$ \\
\hline
\end{tabular}


Table 1-1. Data dictionary.-Continued

[ID, identifier, USGS, U.S. Geological Survey; QAQC, quality assurance quality control; URL, uniform resource locator; NWIS, National Water Information System]

\begin{tabular}{|c|c|c|}
\hline Table heading & Table name & Description \\
\hline Color & Color & $\begin{array}{l}\text { Uses Boolean logic to determine if parameter collected as part of sample (values } \\
\text { of } 1=\text { true). }\end{array}$ \\
\hline PAR & $\begin{array}{l}\text { Photosynthetically active radia- } \\
\text { tion }\end{array}$ & $\begin{array}{l}\text { Uses Boolean logic to determine if parameter collected as part of sample (values } \\
\text { of } 1=\text { true). }\end{array}$ \\
\hline Secchi & Secchi depth & $\begin{array}{l}\text { Uses Boolean logic to determine if parameter collected as part of sample (values } \\
\text { of } 1=\text { true). }\end{array}$ \\
\hline Turb & Turbidity & $\begin{array}{l}\text { Uses Boolean logic to determine if parameter collected as part of sample (values } \\
\text { of } 1=\text { true). }\end{array}$ \\
\hline PhysHab & Physical habitat & $\begin{array}{l}\text { Uses Boolean logic to determine if parameter collected as part of sample (values } \\
\text { of } 1 \text { = true). }\end{array}$ \\
\hline BotSed & Bottom sediment type & $\begin{array}{l}\text { Uses Boolean logic to determine if parameter collected as part of sample (values } \\
\text { of } 1=\text { true). }\end{array}$ \\
\hline SSType & Suspended sediment type & $\begin{array}{l}\text { Uses Boolean logic to determine if parameter collected as part of sample (values } \\
\text { of } 1=\text { true). }\end{array}$ \\
\hline TSS & Total suspended solids & $\begin{array}{l}\text { Uses Boolean logic to determine if parameter collected as part of sample (values } \\
\text { of } 1=\text { true). }\end{array}$ \\
\hline Temp & Temperature & $\begin{array}{l}\text { Uses Boolean logic to determine if parameter collected as part of sample (values } \\
\text { of } 1 \text { = true). }\end{array}$ \\
\hline Radioact & Radioactivity & $\begin{array}{l}\text { Uses Boolean logic to determine if parameter collected as part of sample (values } \\
\text { of } 1=\text { true). }\end{array}$ \\
\hline Toxicity & Toxicity & $\begin{array}{l}\text { Uses Boolean logic to determine if parameter collected as part of sample (values } \\
\text { of } 1=\text { true). }\end{array}$ \\
\hline Birds & Birds & $\begin{array}{l}\text { Uses Boolean logic to determine if parameter collected as part of sample (values } \\
\text { of } 1=\text { true). }\end{array}$ \\
\hline Plants & Plant & $\begin{array}{l}\text { Uses Boolean logic to determine if parameter collected as part of sample (values } \\
\text { of } 1=\text { true). }\end{array}$ \\
\hline MangIss & Management issues addressed & $\begin{array}{l}\text { A list of management issues addressed by data collected. A picklist is provided, } \\
\text { but can be appended by the data user. }\end{array}$ \\
\hline HabDeg & Habitat degradation & $\begin{array}{l}\text { Uses Boolean logic to determine if management issue addressed (values of } 1= \\
\text { true) }\end{array}$ \\
\hline HabRest & Habitat restoration & Uses Boolean logic to determine if management issue addressed (values of $1=$ \\
\hline Contam & Contamination & $\begin{array}{l}\text { Uses Boolean logic to determine if management issue addressed (values of } 1= \\
\text { true) }\end{array}$ \\
\hline SedMang & Sediment management & $\begin{array}{l}\text { Uses Boolean logic to determine if management issue addressed (values of } 1= \\
\text { true) }\end{array}$ \\
\hline NutrEnr & Nutrient enrichment & $\begin{array}{l}\text { Uses Boolean logic to determine if management issue addressed (values of } 1= \\
\text { true) }\end{array}$ \\
\hline Invas $\mathrm{Sp}$ & Invasive species & $\begin{array}{l}\text { Uses Boolean logic to determine if management issue addressed (values of } 1= \\
\text { true) }\end{array}$ \\
\hline LossNat & Loss of native species & $\begin{array}{l}\text { Uses Boolean logic to determine if management issue addressed (values of } 1= \\
\text { true) }\end{array}$ \\
\hline DODepl & Dissolved oxygen depletion & $\begin{array}{l}\text { Uses Boolean logic to determine if management issue addressed (values of } 1= \\
\text { true) }\end{array}$ \\
\hline HABs & Harmful algal blooms & $\begin{array}{l}\text { Uses Boolean logic to determine if management issue addressed (values of } 1= \\
\text { true) }\end{array}$ \\
\hline Pathogen & Pathogens & $\begin{array}{l}\text { Uses Boolean logic to determine if management issue addressed (values of } 1= \\
\text { true) }\end{array}$ \\
\hline Wetland & Wetlands & $\begin{array}{l}\text { Uses Boolean logic to determine if management issue addressed (values of } 1= \\
\text { true) }\end{array}$ \\
\hline
\end{tabular}




\section{Appendix 2}

Table 2-1. Queries used to develop monitoring maps.

[USFWS, U.S. Fish and Wildlife Service; APNEP, Albemarle-Pamlico National Estuary Partnership; SAV, submerged aquatic vegetation;

I\&M, Inventory and Monitoring]

\begin{tabular}{|c|c|c|}
\hline Map name & ArcGIS 10.2 query & Notes \\
\hline $\begin{array}{l}\text { Figure } 3 \text {. Nutrient monitoring in the } \\
\text { Albemarle Sound estuary and rivers }\end{array}$ & $\begin{array}{l}\text { "Active" = } 1 \text { AND "RiverEstua" = } 1 \text { AND } \\
\text { "NutSamp" = } 1\end{array}$ & \\
\hline $\begin{array}{l}\text { Figure 5. Contaminant Monitoring in the } \\
\text { Albemarle Sound estuary and rivers }\end{array}$ & $\begin{array}{l}\text { Contaminant: "Active" = } 1 \text { AND "RiverEs- } \\
\text { tua" = } 1 \text { AND "ContSamp" }=1\end{array}$ & \\
\hline $\begin{array}{l}\text { Figure } 6 \text {. Biological Monitoring in the } \\
\text { Albemarle Sound estuary and rivers }\end{array}$ & $\begin{array}{l}\text { Biology: "Active" }=1 \text { AND "RiverEstua" = } \\
\text { 1 AND "BioSamp" = } 1\end{array}$ & $\begin{array}{l}\text { All Programs recorded as USFWS or APNEP } \\
\text { SAV are removed and the boundaries for } \\
\text { the refuges and sav monitoring map are } \\
\text { shown instead }\end{array}$ \\
\hline $\begin{array}{l}\text { Figure } 7 \text {. Groundwater monitoring sites in } \\
\text { the Albemarle Sound region }\end{array}$ & $\begin{array}{l}\text { "Active" = } 1 \text { AND "ResComp" = 'Ground- } \\
\text { water' OR "ResComp" = 'River/Stream; } \\
\text { Groundwater' }\end{array}$ & \\
\hline $\begin{array}{l}\text { Figure 9. Wetland Monitoring in the } \\
\text { Albemarle Sound region }\end{array}$ & $\begin{array}{l}\text { Wetlands: "Active" = } 1 \text { AND "ResComp" = } \\
\text { 'River/Stream; Wetlands' OR "ResComp" } \\
=\text { 'Wetlands' OR "ResComp" = 'Wetlands; } \\
\text { beaches' }\end{array}$ & $\begin{array}{l}\text { Only locations of USFWS I\&M are shown, } \\
\text { all other USFWS projects are depicted by } \\
\text { refuge boundary }\end{array}$ \\
\hline $\begin{array}{l}\text { Figure } 10 . \text { Beach monitoring in the } \\
\text { Albermarle Sound region }\end{array}$ & $\begin{array}{l}\text { Beaches: "Active" = } 1 \text { AND "ResComp" = } \\
\text { 'Beaches' OR "ResComp" = 'Wetlands; } \\
\text { Beaches' OR "ResComp" = 'Estuary; } \\
\text { Beaches' }\end{array}$ & \\
\hline $\begin{array}{l}\text { Figure } 11 . \text { Nearshore and offshore } \\
\text { monitoring in the Albemarle Sound region }\end{array}$ & $\begin{array}{l}\text { Nearshore/offshore: "Active" = } 1 \\
\text { AND "ResComp" = 'Nearshore' OR } \\
\text { "ResComp" = 'Nearshore; Offshore' OR } \\
\text { "ResComp" = 'Offshore' }\end{array}$ & \\
\hline
\end{tabular}


For further information about this publication contact:

Director

U.S. Geological Survey

North Carolina Water Science Center

3916 Sunset Ridge Road

Raleigh, NC 27607

Or visit the North Carolina Water Science Center Web site at $h$ ttp://nc.water.usgs.gov/

Prepared by the Raleigh Publishing Service Center

A PDF version of this publication is available online at http://dx.doi.org/10.3133/ofr20141110 


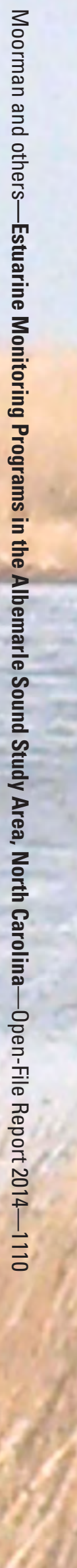

